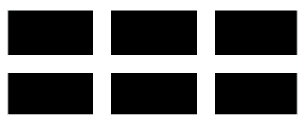

ThE WiLliam DAVIDSON INSTITUTE

AT THE UNIVERSITY OF MICHIGAN BUSINESS SCHOOL

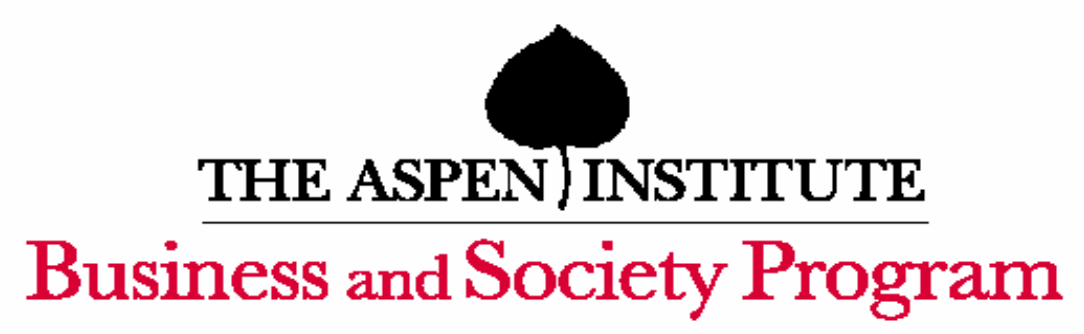

Foreign Direct Investment and the Business Environment in Developing Countries: the Impact of Bilateral Investment Treaties

By: Jennifer Tobin and Susan Rose-Ackerman

William Davidson Institute Working Paper Number 587

June 2003 


\title{
Foreign Direct Investment and the Business Environment in Developing Countries: the Impact of Bilateral Investment Treaties
}

\author{
Jennifer Tobin and Susan Rose-Ackerman ${ }^{1}$
}

November 13, 2003

\begin{abstract}
:
Bilateral Investment Treaty's effects on FDI and the domestic business environment remain unexplored despite the proliferation of treaties over the past several years. This paper asks whether BITs stimulate FDI flows to host countries, and if the treaties have any impact on the environment for domestic private investment. We find a weak relationship between BITs and FDI. However, for risky countries, BITs attract greater amounts of FDI. We also find a weak relationship between BITs and the domestic investment environment. Thus, while BITs may not alter the domestic investment environment, they also may not be fulfilling their primary objective.
\end{abstract}

\footnotetext{
${ }^{1}$ Jennifer Tobin is a graduate student in the Department of Political Science, Yale University. Susan RoseAckerman is the Henry R.Luce Professor of Law and Political Science, Yale University. Email addresses: jennifer.tobin@yale.edu; susan.rose-ackerman@yale.edu.
} 


\section{Introduction}

The impact of multinational firms on developing countries is one of the most hotly contested issues in the current debate over globalization. Much has been written about the macroeconomic impact of foreign investment. Our interest goes beyond these macroeconomic implications to focus on the political and social effects of foreign direct investment (FDI). Our general interest is in the decision-making processes of both foreign investors and host governments. Although these processes are complex and multi-faceted, our focus in this paper is on the role of Bilateral Investment Treaties (BITs), an instrument of growing importance as emerging economies seek to attract foreign investment. This study of BITs is part of our ongoing attempt to understand how foreign investors' and host countries' efforts to limit risk affect the domestic business environment.

Investors always face risks because changes in market prices and opportunities cannot be perfectly predicted ex ante. However, in many developing countries the risk goes beyond ordinary market risk. Investors may have little trust in the reliability and fairness of property rights and government enforcement, and conversely, local businesses, citizens, and politicians may have little confidence in the motives and staying power of international business. Investors complain that the rules are unclear and variable over time. Critics in the host country worry that international investors will reap most of the gains and will flee at the first sign of trouble. In the extreme, the distrust on both sides can be so large that little or no investment takes place, even when this investment would be beneficial to both parties.

Foreign direct investment has frequently been studied as if it were an undifferentiated mass of capital that moves around the world in response to domestic conditions in host countries. We agree that investment is affected by domestic conditions, but we argue that it should be analyzed as a series of deals between host countries and foreign firms that may involve input from the firm's home country as well. Especially in poor and emerging economies, FDI frequently takes the form of large projects each one of which represents a sizable share of the host country's total investment. Therefore, so long as the foreign investor has alternative potential sites for its investment, it has bargaining power vis à vis the host country's government and may be able to negotiate terms that are more favorable than those available to domestic investors. These terms may take the form of exemptions from certain local laws, including tax laws, and of special subsidies and public services, such as new roads and upgraded port facilities. In addition, foreign investors may worry about being exploited by the host country after their investments are sunk and will seek assurances that the government will not treat them worse than domestic firms.

In recent years international investors have been aided by the growth of bilateral investment treaties (BITs). These are treaties signed between the home countries of investors and potential host countries that set a general framework for the negotiation of FDI deals. They bind the host country to treat all foreign investors from the home country in ways that will protect their investments and that give them either parity with or advantages over domestic investors.

The popularity of BITs suggests that many investors are not confident about the legal and political environment in low and middle-income countries. Given this fact, host countries believe they will benefit from signing a treaty that seems on its face quite one-sided in favor of foreign 
investors. The policy questions are then two-fold. First, do BITs stimulate FDI flows to the host country? If the answer to this question is positive, do the treaties encourage certain types of FDI more than others? Second, what is the impact of BITs on the environment for domestic private investment? Is domestic investment stimulated or discouraged by an aggressive effort to sign BITs with many potential investment partners? In other words, is FDI a substitute or a complement for domestic investment, and do BITs encourage countries to improve the protection of domestic property rights?

If countries concentrate on making special deals with foreign direct investors, we speculate that they might neglect measures that improve the investment climate overall. One could study this problem at the level of individual deals to see if their terms permit multinationals to opt out of restrictive local rules or to get better protections from costly government policies. This is an important research priority, but it is beyond the scope of this paper. Instead, we focus on BITS, the one generic policy that clearly singles out foreign direct investors and consider their effects. However, we realize that our results will not be definitive. BITs are a relatively new phenomenon in international business, and their impact is only beginning to be felt.

We proceed as follows. Section II provides a brief overview of the growth and impact of FDI on low and moderate income countries and discusses its relationship to domestic property rights. Section III is an introduction to BITs. Section IV discusses our empirical results. Section V concludes.

\section{Foreign Direct Investment, and Domestic Property Rights}

Both theory and empirical evidence provide mixed results on the benefits versus the costs of FDI. On one side of the debate, scholars suggest that FDI brings new technology and production techniques, raises wages, improves management skills and quality control, and enhances access to export markets. ${ }^{2}$ Some of the costs include stifling of domestic competition and indigenous entrepreneurship, increased income inequality, lower public revenues, an appreciation of the exchange rate and a continuing reliance on local resource endowments, rather than modernization of the productive sector of the economy. Characteristics of the host countrysuch as human capital, labor and wage standards, and the distribution of existing technology across countries, will affect how much countries benefit (or lose) from foreign investment opportunities (World Bank and UNCTAD data sources, Lall and Streeten (1977), Lankes and Venables (1996), Kofele-Kale (1992), and Blomstrom et al. (1996)).

Both the type of FDI and the mode of entry affect FDI's impact on host countries. The existing empirical work has only begun to sort out these complexities. In our view, the inconclusive results arise because the precise impact of FDI varies between industries and countries depending on the characteristics of countries and their policies. ${ }^{3}$ Its impact also depends upon the precise nature of the deal that is struck between the investor, the host country, and any joint venture partners.

\footnotetext{
${ }^{2}$ For overviews of the theory of the influence of FDI on technology transfer see Caves (1996), Findlay (1978), Mansfield and Romeo (1980), Koizumi and Kopecky(1980), Klein et al. (2001), Cooper (2001), and Hanson (2001) ${ }^{3}$ Lankes and Venables (1996), Kofele-Kale (1992), Blomstrom et al (1992).
} 
In poor, high-risk environments FDI is likely to be the major source of investment funds. Regardless of the inconclusive results concerning the pros and cons of FDI, low and middleincome countries view it as a primary means for increased economic growth. Thus, host country governments work to attract FDI. They offer incentives to multinational corporations (MNCs) designed to attract FDI from competing countries and to offset potential risk factors that might deter investment. Likewise, MNCs employ strategies to reduce the potential risk of investing in unstable environments.

Over the period 1995-2000, FDI inflows grew at an annual average rate of 17 per cent for low and middle-income countries. ${ }^{4}$ Although inflows of FDI to such countries continue to grow yearly, their share of world FDI flows recently began to decline. FDI inflows to developing countries grew from US\$187 billion in 1997 to $\$ 240$ billion in 2000, although their share of world FDI decreased to 19 per cent in 2000 down from 21 per cent in 1999 and 27 per cent in 1998 (figure 1a and 1b). ${ }^{5}$ FDI continues to be the largest source of external finance for developing countries, exceeding the sum of commercial bank loans and portfolio flows in most years (figure 2). It is also more stable than financing from other external sources. Between 1997 and 2001, FDI was relatively flat as a share of the GDP of developing countries, but the ratio between FDI and non-FDI flows varied from 4.6 to 1.8 .

[Insert figures 1a, 1b, and 2 here]

There are two principal ways to attract FDI, which may be complements or substitutes. The first is to establish special, favorable conditions for FDI that do not apply to all investment; the second is to improve the overall politicalleconomic environment to reduce risk. One way to reduce risk is to have clearly defined and enforced property rights. Well enforced property rights not only leads to greater amounts of current domestic investment, ${ }^{6}$ but also creates a stable

\footnotetext{
${ }^{4}$ FDI inflows are defined as the gross level of FDI flowing into a region over a period of time (usually one year). FDI stock is defined as the total accumulated value of foreign owned assets at a given point in time. Developing countries are defined according to the World Bank's income classifications, based on gross national income (GNI) per capita. The category 'Developing countries' includes low-income, lower-middle income, and upper-middle income countries. See appendix A for exact classifications.
}

\footnotetext{
5 All dollar figures are in constant 2000 US dollars.

${ }^{6}$ Douglas North (1990) argues that inefficient property rights are "the most important source of both historical stagnation and contemporary underdevelopment in the Third World." Hernando De Soto (2000) claims that property rights help people to borrow more easily and overcome the information constraints that enable markets to function efficiently. In Firmin-Seller's (1995) study of property right in Ghana, she found that the key to the state's economic success lay in the ability of the government to enforce property rights through its political institutions. Knack and Keefer (1995) offer evidence that "institutions that protect property rights are crucial to economic growth and investment." Likewise, Goldsmith (1995), using cross-sectional data found a correlation between property rights and economic growth in low and middle-income countries. In a firm level study of political risk in developing countries, Borner, Brunetti and Weder (1993) found that "if political uncertainty is present, economically sound domestic investments are rare...institutional reform is therefore a crucial precondition for market-driven development that depends primarily on private sector investment." Torstensson (1994) found that "insecure property rights result in an inefficient allocation of investment funds and an inefficient use of human capital." Taking into account the time dimension of economic growth, David Leblang demonstrated that nations that protect property rights grow faster than those that do not. Stepping back to look at overall policies that affect not only overall growth, but also the incomes of the poor, Dollar and Kraay (2001) found that basic packages of good policies, within which property rights plays a vital role, raise overall incomes in developing countries and have an additional positive impact on the
} 
market environment that can promote FDI. Confidence in the enforcement of property rights reduces the incentive to insure against political risk and reduces the cost of doing business (Abbott 2000). Studies on corruption and political risk show that foreign investors prefer to do business in environments with well-enforced property rights. ${ }^{7}$

If strong property rights are desirable for both domestic and foreign investors, why don't countries simply replicate the property rights systems of western capitalist societies? One reason is that most developing country governments do not have the legal systems and institutional structures in place to adequately enforce laws. In other cases, it is simply not in the best interests of governments to create or enforce strong property rights. Such governments cannot make credible commitments not to violate their own country's rules. It is only when the benefits of property rights enforcement outweigh the benefits of low levels of enforcement that governments will strengthen enforcement. ${ }^{8}$ Governments in countries with weak property rights may seek to attract FDI by making special deals with investors that do not have to be extended to the domestic economy as a whole, or even undermine domestic protections. ${ }^{9}$

\section{Bilateral Investment Treaties}

Given the weakness of the domestic politicalllegal environment in many low and middle-income countries, investors seek alternatives tailored to their needs. This can be done on a case-by-case basis, but transaction costs can be reduced if the host country commits itself to a basic framework. This is what BITs do. They provide clear, enforceable rules to protect foreign investment and reduce the risk faced by investors. According to UNCTAD's comprehensive overview of BITs, the treaties promote foreign investment through a series of strategies, including guarantees of a high standard of treatment, legal protection of investment under international law, and access to international dispute resolution (UNCTAD 1998). They are becoming a more and more popular tool for developing countries to promote and protect foreign investment.

The first BIT was signed in 1959 between Germany and Pakistan and entered into force in 1962. The number of new BITs concluded rose rapidly in the 1990s. According to UNCTAD, the overall number of BITs rose from 385 in 1990 to 1,857 at the end of 1999. As of the end of 1999, 173 countries were involved in bilateral investment treaties (figure 3). Most early treaties were signed between a developed and a developing country, generally at the urging of the developed country governments. Typically, before the 1990s, developing countries did not sign BITs with each other, but throughout the 1990s more and more developing countries have been signing the treaties with each other (figure 4).

incomes of the poor. Likewise, Hall and Jones (1999) found that differences in government policy and institutions, with property rights playing a major role, equated to large differences in income across countries.

${ }^{7}$ Although a number of authors have hypothesized this link, Anderson's studies of corruption in Eastern Europe confirm the relationship. See for example, Anderson et al (2003) and Anderson (1998, 2000). See also Goldsmith (1995), LeBlang (1996), and Grabowski and Shields (1996).

${ }^{8}$ See Barzel (1989) and Firmin-Sellers (1995). Borner et al (1995) confirms Firmin-Sellers finding in their study of property rights and investment in Ghana.

${ }^{9}$ For example, Hernando De Soto argues that without clear ownership, land can be stripped from the poor to make way for government and foreign-led industrialization projects (De Soto 2000). 
The proliferation of BITs has followed a general geographic pattern. Most early BITs were signed between African and Western European Countries. Asian nations slowly began to enter the arena in the 1970s, followed by central and eastern European countries. It was not until the late 1980s that Latin American nations began to enter into these agreements (figure 5). ${ }^{10}$

\section{A. BITs: History}

International law on commerce and investment originally developed out of a series of Friendship, Commerce, and Navigation treaties (FCNs) and their European equivalents. They were part of the US Marshall Plan that was meant to reinvigorate the European economy after World War II. FCNs provided foreign investors with most favored nation treatment in host countries, but were mainly signed between developed countries. The United States also attempted to protect foreign investors through investment guarantees and legal provisions. The Overseas Private Investment Corporation (OPIC) was established to protect investment in postwar Europe and was expanded to developing countries in 1959. Further, the U.S. Congress passed the Hickenlooper amendment requiring the U.S. government to terminate aid to any country that expropriated property from a U.S. investor without adequate compensation. The amendment was used only twice and did not serve its purpose in deterring investment (Mckinstry Robin 1984).

In 1967, the OECD attempted to establish a multilateral agreement on foreign investment protection - the OECD Draft Convention on the Protection of Foreign Property. The convention proposed an international minimum standard of protection for foreign investment but was opposed by developing countries, mainly in Latin America, that insisted on subjecting foreign investment to domestic control with disputes being settled in domestic courts. ${ }^{11}$ Following the failure of the OECD convention, European countries and later the United States began to establish more and more bilateral investment agreements with developing countries. ${ }^{12}$

\section{B. BITs: Basic Provisions}

Overall, the provisions of BITs are meant to secure the legal environment for foreign investors, establish mechanisms for dispute resolution, and facilitate the entry and exit of funds. BITs cover expropriation of property as well as indirect takings that are tantamount to expropriation. BITs are currently the dominant means through which investment in low and middle income countries is regulated under international law (Kishoiyian 1994, Schwarzenberger 1969, Walker

10 Although Latin American countries were not signatories to BITs until the 1990s, their largest trading partner, the United States, provided political risk insurance and guarantee agreements to most Latin American Nations.

${ }^{11}$ In 1974, a number of developing countries supported a United Nations resolution to protect the national sovereignty of the economic activities and resources of host countries (Charter of Economic Rights and Duties of States, G.A. Res. 3281, 29 U.N. GAOR Supp. (No.31) at 50, 51-55, U.N. Doc. A/9631 (1974)).

${ }^{12}$ European treaties are generally known as Bilateral Investment Protection Agreements (BIPAs) although the U.S. treaties are known as BITs. The United States Bilateral Investment Treaty program did not begin until 1982 with its treaty with Panama. The United States signed twenty-three FCNs between 1946 and 1966, but did not enter into any other bilateral agreements on investment until the 1982 BIT with Panama. Shenkin (1994) attributes this to a reluctance on the part of developing countries to enter into FCNs with the United States as well as the attractiveness of the European BIPA program. 
1956). The treaties are a response to the weaknesses of customary international law under which foreign investment is subject exclusively to the territorial sovereignty of the host country (UNCTAD 1998).

The majority of BITs ${ }^{13}$ have very similar provisions. The major differences lie in the protection or non-protection of certain types of investment. The need for developing countries to retain control over certain types of investments and resources restricts the establishment of an international agreement on investment.

As with their predecessors, the FCNs, BITs provide national or most-favored-nation treatment to foreign investors in the host country. However, most BITs contain clauses that exclude investments in particular areas such as national security, telecommunications, and finance. National treatment ensures foreign investors the right to establish any business that the host government would have allowed a domestic investor to establish. National treatment is not followed in all BITs. Some limit treatment to that considered "fair and equitable," although some require that all foreign investments gain approval regardless of the domestic situation (McKinstry Robin 1984). Further, the US model treaty as well as many European BITs establish the right of the investor to transfer all earnings to the investing country.

BITs generally provide for resolution of investor-host country disputes by the World Bank Group's International Center for the Settlement of International Disputes (ICSID) as a background provision (UNCTAD, 1998). In spite of these provisions, official sanctions against countries not complying with BITs tend to be weak. However, violations of these treaties should result in future reluctance of both the partner country and new countries to sign further treaties, loss of faith in existing treaties, and lack of faith in the investment environment in the host country. Thus, although only a small number of investment disputes have been heard by ICSID, hundreds of disputes are negotiated between interested parties because of the binding nature of ICSID arbitration (Shenkin 1994).

Typically, developed countries prepare a model treaty based on the 1967 Draft Convention on the Protection of Foreign Property and on already existing BITs (UNCTAD 1996). ${ }^{14}$ These model treaties are then modified for use in a variety of situations. Thus, treaties emanating from a developed country are likely to be similar or even identical, but differences exist between those proposed by different developed countries. The principal aim of the treaties is to outline the host country obligations to the investors of the home country.

\section{The Impact of BITs on Developing Countries}

\section{Costs and Benefits of BITs}

\footnotetext{
${ }^{13}$ We will use BIT to refer to both BITs and BIPAs. The main difference between BITs and BIPAs is the prohibition in BITs of investment performance requirements.

${ }^{14}$ For an example of a model treaty see Appendix B, 1994 US draft treaty.
} 
Developing countries employ BITs as a means to attract inward investment. The protections to foreign investment are presumed to attract investment flows to developing countries that will lead to economic development. Developing countries hope that the treaties signal to foreign investors either a strong protective investment environment or a commitment that foreign investments will be protected through international enforcement of the treaty.

Beyond attracting investment, developing countries hope that BITs will have peripheral benefits. For example, binding foreign investment disputes to international arbitration may serve not only as a signal that the current government is friendly towards FDI, but it may also lock future governments into the same policy stance. Further, BITs may provide symbolic benefits to the current government. For example, signing a BIT may signal a willingness to sign international treaties in other areas. For countries in transition, BITs may provide a shortcut to policy credibility in the international arena (Martin and Simmons 2002).

These benefits must be balanced against the costs. Although developing countries may enter into the treaties in the hopes of obtaining peripheral benefits, some countries may be forced to sign the treaties to compete with similar countries. For example, if two countries offer relatively similar investment environments and one signs a BIT with a major foreign investor, the other country may agree to sign a similar treaty-regardless of the potentially negative impacts of that treaty-simply to remain on par with the competing country.

BITs may facilitate a division of profits that is less favorable than might occur under other regimes less highly controlled by the developed countries. They may also have negative consequences for domestic investors if they are treated less well relative to foreign investors. MNCs argue that BITs only level the playing field for them relative to favored domestic investors, but it is at least possible that the scales may end up tilted in favor of the foreign investors.

Developing countries fear a loss of control over their internal economic activity through restrictions on their employment and development policies as well as through challenges to national industries. The loss of sovereignty over domestic investment disputes may be too high a burden for some developing countries and lead them to refuse to sign BITs (Kahler 2000). In the early 1980s, the US BIT with Honduras was stalled for a few years because clauses in the draft treaty violated Honduran legislation. For example, in 1984, Honduras was counting on US\$5 billion of US investment, but refused to sign the BIT because of the sovereignty issues at stake. ${ }^{15}$

The US BITs and several European BITs prohibit investment performance requirements. Although this may lead to an end of a race to the bottom to attract investment in terms of tax holidays or other incentives, it may also take away from the host country leverage over foreign investors. Investment performance requirements enable host countries to influence the trading and locational decisions of foreign investors in favor of host country development. For example, export requirements can improve the balance of payments accounts of a host country and locational incentives can aid the infrastructure development of the host country. The costs versus the benefits of the removal of investment incentives have yet to be studied, but the loss of

15 Torres, Manuel. "Honduras: Trade Talks With U.S. At Standstill.” Inter Press Service, April 3, 1984. 
performance requirements may mean the loss of a key benefit of FDI for developing countries (Shenkin 1994).

A claim of expropriation under a BIT may be resolved through a judgment that requires the host country to pay compensation to the investor. In the absence of BITs, developed countries push for application of their own legal guidelines for "prompt, adequate and effective compensation," and developing countries have long insisted that only host countries' domestic tribunals can decide upon appropriate compensation. BITs protect investments from developed countries with violations subject to dispute resolution through ICISD (Kishoiyian 1994).

Repatriation of profits is another area that may have negative consequences for developing countries. The majority of treaties grant the investor the ability to repatriate profits "without undue delay". At the same time, many of the treaties guarantee the host country the ability to delay the repatriation of profits in times of economic emergency. ${ }^{16}$ If the treaties are interpreted to give a narrow reading to the term "economic emergency," the ability to repatriate profits could intensify liquidity problems faced by host countries (Kishoyian 1994, McKinstry Robin 1984). This issue may arise in the case of the French-Argentinean BIT. Suez, a French water and energy firm that has invested in Argentina, is suing the government of Argentina under the expropriation provisions of their BIT for compensatory damages following the devaluation of the peso. Although this case is still pending, the validity of the claim under the BIT is worrisome for the economic situation in Argentina. ${ }^{17}$

Nearly all BITs contain clauses that give firms the right to petition governments for damages stemming from environmental or health regulations enacted after investment has taken place. Firms have successfully sued for damages under an equivalent clause in NAFTA. Specifically, firms have been able to claim that newly enacted environmental and health regulations amount to the expropriation of profits. A Spanish waste management firm has brought about such a case. Tecnicas Medioambientales SA, is suing the Mexican government under the provisions of the Spain-Mexico BIT for damages resulting from new environmental regulations. The result of this type of clause may keep governments that have signed BITs from enacting new environmental, health, or labor regulation for fear that they could be sued under existing BITs. ${ }^{18}$

Finally, and perhaps most importantly for our purposes, is the issue of dispute settlement. Foreign investors have recourse to international arbitration tribunals to settle any claims resulting from what they believe to be unfair treatment of their property. Domestic investors are left to the property rights enforcement systems that developed country investors can avoid through BITs.

\section{Property Rights and BITs}

\footnotetext{
${ }^{16}$ Kishoiyian(1994) points to an ICSID study of 335 BITs. All provided for the immediate repatriation of profits, but 60 enabled the host country to take into account its balance of payments situation in the country, and many provided for interest or set the precise rate of exchange in the event of a delay.

${ }^{17}$ EFE News Service, June 28, 2002. France-Argentina French Firm To Press Argentina For Indemnization On Losses.

${ }^{18}$ Peterson, Luke. “Opinion Debate Over Investor Rights Is Too Late.” The Toronto Star. April 22, 2001.
} 
Given the mixed impact of BITs, we would expect that low and middle-income countries will vary in their enthusiasm for BITs and in their insistence on the inclusion of exceptions. For example, resource rich countries have an advantage in bargaining with foreign investors. Therefore, we would expect resource rich states to try to avoid signing such treaties or to sign treaties with favorable clauses; in contrast, states with few distinctive benefits to offer investors need to sign BITs (Kahler 2000 and Abbott 2000). Countries competing for the same types of investment need to mimic the policies of competing countries, or they risk placing themselves at a disadvantage. Thus, we would expect that if one country signs a BIT as a signal to foreign investors that their investments will be protected, this will encourage similar countries to act likewise.

Weak countries may sign BITs to constrain stronger states, but in the process they must accept a deal that is very favorable to the stronger state. Only risk-takers will invest in countries such as Somalia, the Congo and Tanzania; these investors are likely mainly to care about natural resources, thus overall domestic investment remains minimal. Even if these countries signed BITs, it is unlikely that investors would rely on the treaties to assure investment protections. In contrast, a few middle-income countries, such as Korea, Chile, and Singapore, have broken the property rights barrier and are considered to be low investment risks. Firms have confidence that those countries will enforce the property rights of all investors. In these countries, BITs vary more from the model treaties than in other developing countries. Their stable investment environment enables them to negotiate over the terms or even to refuse to sign treaties without risking a lost of foreign investment. For example, Singapore refused to enter into a BIT with the United States based on its model treaty because of the limits on performance requirements. Further, its treaties with France, Great Britain, and the Netherlands limit the protection offered to investors to specifically approved investment projects (Kishoiyian 1994).

The middle cases are the most interesting to us. These cases lie at mid-point of property rights evolution and could either stagnate or move forward. On the one hand, without BITs competition for foreign investors could encourage property rights reform - perhaps aided by small domestic investors who realize the potential benefits of establishing a rule of law. On the other hand, domestic elites and corrupt bureaucrats might attempt to maintain the status quo. A governmental decision to reform property rights is unlikely if the rents are derived from the nonenforcement of property rights are high, if incumbents do not expect to gain many benefits from reform (perhaps because they risk losing political power) and, most importantly, if the power of the opposing interest groups is high.

Without BITs, improvements in property rights enforcement come from government decisions to foster economic growth through increased foreign and domestic investment. But, this will only occur when the benefits of increased investment, combined with any political capital gained from those changes, outweighs the costs of enforcement and the political losses from those who lose out from the new system. The trade literature has demonstrated that foreign investors have a great deal of power in host country political decisions. Thus, in the absence of BITs, these investors might be advocates of broader reforms that could benefit all investors. In contrast, a world with BITs reduces the interest of MNCs in property rights reform and enforcement in developing countries. Domestic reform may be less likely and the country may even regress toward policies that harm domestic investors. In some countries, attempts at reform fail, or no 
attempts at reform are made at all. In such cases, the BIT, although benefiting foreign investors, can have a negative effect on the trustworthiness of the business environment for domestic investors.

It is instructive to mention a few cases that indicate the possible disjunction between property rights and BITs. In many countries, western donor agencies, especially USAID, in conjunction with the local chamber of commerce, work to establish local arbitration tribunals to deal with investment disputes. USAID also promotes BITs to overcome the exact problems that the local arbitration tribunals were meant to deal with. Thus, if BITs prove effective, the pressure for property rights reform that was evident through these local tribunals may well be scaled back.

Botswana and Namibia have the highest property rights rankings of all countries in sub-Saharan Africa in both the International Country Risk Guide (ICRG) and the Heritage Foundation, two generally accepted ratings of property rights. Yet, as of 2000, Botswana was a signatory to two BITs, only one of which is with a developed country (Switzerland) and Namibia has signed only five. Zimbabwe and South Africa, neighboring countries with significantly lower rankings on the property rights scale, have signed 24 and 18 BITs, respectively.

In Latin America, cases do not stand out as clearly. However, Peru and Venezuela, two countries that both embarked on specific programs of property rights reform and failed are well above the mean for BITs in the remainder of Latin America. Specifically, Peru and Venezuela have signed 26 and 22 BITs respectively, with the mean for Latin America below 14. Peru's attempt at reform is notable. A program to reform the property rights system and ensure its enforcement was supported by a grant from the World Bank. Additionally, a well-known local non-governmental organization initiated a public information campaign to inform potential investors of the benefits of property rights. Yet the program was terminated a year and a half into the project, before actual implementation ever began. ${ }^{19}$ It is, of course, unlikely that BITs played the primary role in impeding property rights enforcement reform in Peru. However, a lack of pressure from major investors for reform appears to have played a major role.

\section{Conclusions}

Many observers of the global business environment view the growing internationalization of commercial law, through BITs and international arbitration, as a desirable trend. They urge its expansion to cover a broader range of contract disputes. However, although international commercial law norms and BITs reduce risk and solve collective action problems, their impact on social welfare is ambiguous. They may impose "discipline" on governments that would otherwise favor narrow interests or demand corrupt payoffs (Waelde 1999). Alternatively, these standards may reduce a nation's flexibility in negotiations and lead it to favor outside investors or narrow local interests over the general population. Because BITs are based on models drafted by capital exporting states and express little concern with improving the overall legal structures of developing countries, they may reduce the available benefits to the host country from FDI (Guzmán 1997).

\section{Quantitative Analysis}

19 LCHR (2000) and The Economist. “The dark side of the boom,” August 5, 1995 
An empirical analysis of the effects of BITs requires a two-pronged approach. First, we look at how BITs interact with other determinants of foreign investment to affect FDI inflows. The main benefit of BITs is purported to be increased FDI to developing countries, this analysis takes the first step towards understanding if this is true. Second, we analyze the effects of BITs and the domestic business environment through their effects on domestic private investment and on property rights.

The data for our study are based on various indicators of government performance, investment rates, social indicators, and investment treaties in up to 176 countries. The datasets were compiled from a variety of sources and therefore contain a different number of observations for different variables. The data sets use panel data from the first BIT signed in 1959 through 2000 for low and middle-income countries ${ }^{20}$ to take into account the dynamic nature of some of the data, and to control for some of the statistical problems inherent in cross sectional analyses of this type.

\section{A. FDI}

There is a broad empirical literature on the determinants of FDI. ${ }^{21}$ A review of the literature shows that there is no clear agreement on the factors that determine FDI inflows to developing countries. The studies use diverse variables and often come to opposing findings on the relationship between certain variables and investment. Nevertheless, we can use past work to specify a reasonable model for the determinants of investment as a basis for understanding the impact of BITs. We break our analysis into two parts, a general analysis to determine the impact of signing the treaties on overall FDI inflows and a bilateral analysis between the United States and low and middle income countries.

\section{General Analysis}

As the dependent variable for our general analysis we use the broadest measure of FDI inflows available on a yearly basis from UNCTAD. ${ }^{22}$ We measure FDI as inflows to a particular country as a percentage of world FDI inflows for that year. In this case we are interested in how each country's fraction of world FDI inflows increases (or decreases) based on the number of treaties signed. The ratio of inflows to a particular country for each year to overall FDI flows to all countries is the best measurement of change in the fraction of world FDI. ${ }^{23}$ FDI inflows are provided on a net basis, and include capital provided (either directly or through other related enterprises) by a foreign direct investor to an FDI enterprise or capital received from an FDI

\footnotetext{
${ }^{20}$ Appendix D contains a list of countries used in each analysis. Appendix F contains correlations between variables in each of the analyses.

${ }^{21}$ Chakrabarti(2001) offers a good overview of the literature on the determinants of FDI. For more specific analyses, see for example: Schneider, F. and B. Frey (1985), Root and Alimed (1979), Sader (1993), Billington (1999), Markusen (1990), Gastanaga et al (1998), Ozler and Rodrik(1992), and Henisz(2000).

${ }^{22}$ See appendix $\mathrm{E}$ for sources and definitions of variables and appendix F for summary statistics.

${ }^{23}$ We re-ran the models using FDI as a percentage of GDP, and the results did not change significantly. This ratio, however, measures changes in the importance of FDI to the overall economy, rather than changes in inflows, the measure we are interested in, so we retained our ratio of FDI inflows to overall FDI flows.
} 
enterprise by a foreign direct investor. There are three components in FDI: equity capital, reinvested earnings, and intra-company loans. If one of these three components is negative and is not offset by positive amounts in the remaining components, the resulting measure of FDI inflows can be negative, indicating disinvestment. ${ }^{24}$

Market size is universally accepted as the leading determinant of FDI inflows. We use two proxies that, taken together, indicate the value of investing to serve a country's market. The first is the log of GDP per capita, and the second is population. Beyond market size, there is general disagreement on the determinants of FDI. Theoretically, the rate of growth of a country's economy would seem to be important for attracting FDI, as a fast growing economy in the present would indicate future development potential (Schneider and Frey 1985). We are interested in understanding how growth, market size, and BITs affect subsequent foreign investment. However, although growth and market size affect the level of investment in a country, it is also likely that the opposite direction of causation operates as well. That is, higher investment leads to greater growth and a larger market. We deal with this problem by lagging these variables in one case, and instrumenting for them with their lagged value in our second case.

Black market premia are a symptom of overvaluation of national currencies and thus are likely to relate to lower levels of investment. They are often used in empirical evaluations as a proxy for distortions in the financial system. The black market premium is taken from the IMF's International Financial Statistics and is defined as the ratio of the black market exchange rate and official exchange rate minus one.

According to UNCTAD (2001), the majority of FDI to the least developed countries is through natural resource investment. The presence of natural resources in a country is expected to attract foreign investment regardless of other factors that would usually attract or discourage investors. Natural resource endowments are measured through a composite of natural fuels and ores exported from individual countries, available from the IMF's International Financial Statistics Database.

We include political risk as a potential determinant of FDI inflows, theorizing that countries with high levels of political risk will attract less investment then those with low levels of risk. There are several readily available measures of political risk. For the purpose of cross-sectional comparison across time, and to have the ability to separate out factors such as property rights risk in our subsequent analysis, we use a measure produced by the International Country Risk Guide (ICRG). Their variable is based on institutional indicators complied by private international investment risk services. The ICRG political risk index utilizes measures of the risk of expropriation, established mechanisms for dispute resolution, contract enforcement, government credibility, corruption in government, and quality of bureaucracy. It is measured on a scale from one to 100 (the individual components are available in appendix C) with higher numbers equating to lower (better) levels of risk in a country.

\footnotetext{
${ }^{24}$ For more information see the World Investment Directory Website: http://r0.unctad.org/en/subsites/dite/fdistats_files/WID.htm
} 
Other independent variables are also readily available for analysis, including measures of human development, level of democracy, and geography. To account for country specific factors, we also include a continent dummy and, latitude, a variable equal to the distance of the country from the equator, scaled between 0 and $1 .^{25}$ Theories of institutions and economic growth claim that countries in more temperate zones have more productive agriculture and healthier climates, enabling more highly developed economies and institutions (Landes 1998, La Porta et al 2000). Social factors such as literacy or health are highly collinear with our measures of market size and growth and were therefore excluded from the model.

Depending on the type of FDI, the level of openness (measured as exports plus imports to GDP) could have a positive or negative impact on a country's ability to attract FDI. FDI focused on exploiting the local market would be attracted to a country with a less open economy, and FDI focused on the tradeables sector would be positively related to openness. The opposing nature of the theory as well as gaps in the data for our sub-sample of countries led us to exclude openness from our estimation. Likewise, we exclude inflation from our analysis, as we expect the impact of inflation to be ambiguous. On the one hand, if lending is done in the local currency, unanticipated inflation benefits debtors. On the other hand, high inflation rates may indicate domestic policy failures that discourage both savings and investment. ${ }^{26}$ Further variables that could act as determinants of FDI that we excluded because of opposing theory or data inefficiencies include the host country's wage, government consumption, and tax rates. The host country wage has been shown in various studies to be both an inducement and a deterrent to FDI based on the type of investment. For example, Schneider and Frey (1985) and Pistoresi (2000) found that higher wages tended, on average, to discourage FDI, although Caves (1974) and Wheeler and Mody (1992) found a positive association between FDI inflows and the real wage. Tax rates do not let us separate out tax incentives to attract investment from high tax rates that deter FDI. ${ }^{27}$ Likewise, overall measures of government consumption do not permit one to separate out that which types of spending attract investment and that which are deterrents.

Data on BITs are available from a listing published by UNCTAD that documents the parties to every bilateral investment treaty, the date of signature, and the date of entry into force. These data are available for every BIT of public record from the first treaty signed in 1959 between Germany and Pakistan through December 2000 (UNCTAD 2000). Because of the long-term nature of BITs, we measure our BIT variable as the cumulative number of BITs signed by a particular country. We separate out those BITs signed with developed countries from those signed with developing countries to determine if the treaty partner might have some effect on the investment or property rights level in the host country.

\footnotetext{
${ }^{25}$ We also considered including legal origin in our analysis. However, the meaning of this variable is in doubt. It may simply be capturing general historical regularities. For purposes of robustness we included it in one version of our random effects specification, but it's coefficient estimates across specifications was zero and insignificant, and its inclusion did not affect the remaining variables.

${ }^{26}$ Inclusion of inflation in our specifications does not change the results on the remaining variables and resulted in insignificant coefficient estimates.

${ }^{27}$ We included measures of taxes on goods and taxes on income available from the IMF's International Financial Statistics in both sets of regressions on FDI and private investment. The coefficients were equal to zero and not statistically significant in any regression. This, in addition to the problems discussed in the text, led us to exclude them from the analyses.
} 
To avoid the impact of year-to-year variation caused by the pattern of individual deals, we use five year averages for the BIT data for the period 1975 to $2000 .^{28}$ To limit the problem of simultaneity, we measure the potentially endogenous variables at the beginning of each five year period and our dependent variables at the end of each period.

We chose to model the data in two forms. First, to account for differences across countries, we run a random effects generalized least squares regression with panel corrected standard errors as suggested by Beck and Katz (1995). In this model we account for the possible endogeneity of our regressors by measuring FDI at the end of the period and market size, political risk, and growth at the beginning of the period. All other variables are measured as the average over the five-year period.

Our primary specification for foreign direct investment to low and middle income countries is as follows:

$$
Y_{i t}=\alpha_{i}+B \mathbf{X}_{i t}+\not \mathbf{D}_{i}+v_{i t}
$$

Where $\mathrm{Y}$ is a vector of FDI inflows as a percentage of world FDI, X represents a matrix of potential determinants of FDI that can change across time, including BITs; D likewise represents a matrix of possible determinants of FDI, but these are country-specific factors that do not change across time. The subscript i represents country $i$ and the subscript $t$ represents time period t.

Our second specification accounts for changes within countries across time. We model a generalized least squares, fixed effects model. This model takes into account the endogeneity problem by instrumenting for growth and market size with their lagged values. Our remaining variables, natural resources, black market premia, and political risk are measured as the average over the five year period.

Thus our second model is:

$$
Y_{i t}=\alpha_{i}+B \mathbf{X}_{i t}+\mu_{i} \mathbf{Z}_{i}+v_{i t}
$$

where all other variables remain the same, but $\mathrm{D}$, the vector of independent variables that do not change across time is omitted, and $\mathrm{Z}$ is a matrix of individual dummies to measure unobservable country-specific effects.

28 Although some of our data goes back to 1959, the bulk of the data covers 1975 to 2000 . 
A Hausman specification test rejected the assumption that the error component from the random effects model was uncorrelated with the error in that model. Thus, our random effects model will be less efficient then our fixed effects model. However, because of the paucity of the data across time for a number of our countries, we felt that it was important to examine the implications of both models. 
Table 1

FDI and Bilateral Investment Treaties: Random Effects Model (1980-2000)

\begin{tabular}{|c|c|c|c|c|c|}
\hline & Base Case & 2 & 3 & 4 & 5 \\
\hline $\begin{array}{l}\text { Run: BITs signed with } \\
\text { High income }\end{array}$ & & & $\begin{array}{l}0.0670 * \\
(0.0329)\end{array}$ & & $\begin{array}{c}-0.00380^{\wedge} \\
(0.109)\end{array}$ \\
\hline $\begin{array}{l}\text { Run: BITs signed with } \\
\text { low income }\end{array}$ & & & $\begin{array}{r}-0.0860 \\
(0.0581)\end{array}$ & & $\begin{array}{l}-0.0491^{\wedge} \\
(0.288)\end{array}$ \\
\hline $\begin{array}{l}\text { Run: BITs signed with } \\
\text { Total }\end{array}$ & & $\begin{array}{l}0.0160 * \\
(0.0091)\end{array}$ & & $\begin{array}{l}-0.00720^{\wedge} \\
(0.0672)\end{array}$ & \\
\hline Natural log GDP per capita & $\begin{array}{l}0.139 * * \\
(0.019)\end{array}$ & $\begin{array}{r}0.132^{*} \\
(0.0126)\end{array}$ & $\begin{array}{r}0.118^{*} \\
(0.0113)\end{array}$ & $\begin{array}{l}0.129 * \\
(0.0045)\end{array}$ & $\begin{array}{l}0.114 * * \\
(0.0153)\end{array}$ \\
\hline Political Risk & $\begin{array}{l}0.0116 * * \\
(0.0053)\end{array}$ & $\begin{array}{l}0.0109^{*} \\
(0.0049)\end{array}$ & $\begin{array}{l}0.0111^{*} \\
(0.00523)\end{array}$ & $\begin{array}{l}0.00980^{*} \\
(0.00111)\end{array}$ & $\begin{array}{l}0.00892 * * \\
(0.00261)\end{array}$ \\
\hline Risk*Total BITs & & & & $\begin{array}{l}0.000450^{\wedge} \\
(0.00149)\end{array}$ & \\
\hline Risk*lowincome BITs & & & & & $\begin{array}{l}-0.000720^{\wedge} \\
(0.00608)\end{array}$ \\
\hline Risk*highincome BITs & & & & & $\begin{array}{c}0.00124^{\wedge} \\
(0.00260)\end{array}$ \\
\hline Black Market Premium & $\begin{array}{r}0.00393 \\
(0.00607)\end{array}$ & $\begin{array}{l}0.00098 * \\
(0.00056)\end{array}$ & $\begin{array}{r}0.00140 \\
(0.00878)\end{array}$ & $\begin{array}{l}0.000824 * \\
(0.00043)\end{array}$ & $\begin{array}{l}0.00110 * * \\
(0.000430)\end{array}$ \\
\hline Natural log Population & $\begin{array}{l}0.209 * * \\
(0.0140)\end{array}$ & $\begin{array}{r}* \\
0.218 * \\
(0.0090)\end{array}$ & $\begin{array}{r}* \\
0.230 * \\
(0.00944)\end{array}$ & $\begin{array}{r}* \\
0.221 * \\
(0.00745)\end{array}$ & $\begin{array}{l}0.234 * * \\
(0.010)\end{array}$ \\
\hline Growth & $\begin{array}{l}(0.0008) \\
(0.0146)\end{array}$ & $\begin{array}{r}0.00046 \\
(0.0144)\end{array}$ & $\begin{array}{r}0.0020 \\
(0.0143)\end{array}$ & $\begin{array}{r}0.000381 \\
(0.0144)\end{array}$ & $\begin{array}{l}0.00168 \\
(0.0137)\end{array}$ \\
\hline Natural Resources & $\begin{array}{r}-0.00021 \\
(0.0015)\end{array}$ & $\begin{array}{l}0.00015 \\
(0.0014)\end{array}$ & $\begin{array}{r}0.000092 \\
(0.00136)\end{array}$ & $\begin{array}{l}0.000217 \\
(0.00134)\end{array}$ & $\begin{array}{r}0.000206 \\
0.00142\end{array}$ \\
\hline Latitude & $\begin{array}{l}-0.246^{* *} \\
(0.101)\end{array}$ & $\begin{array}{r}* \\
-0.118 * \\
(0.024)\end{array}$ & $\begin{array}{r}0.322 \\
(0.345)\end{array}$ & $\begin{array}{r}-0.0926 \\
(0.0843)\end{array}$ & $\begin{array}{r}0.370 \\
(0.398)\end{array}$ \\
\hline Latin America & $\begin{array}{l}0.279 * * \\
(0.116)\end{array}$ & $\begin{array}{r}0.395^{*} \\
(0.0493)\end{array}$ & $\begin{array}{r}0.524^{*} \\
(0.0742)\end{array}$ & $\begin{array}{c}0.404^{*} \\
(0.020)\end{array}$ & $\begin{array}{l}0.540 * * \\
(0.0790)\end{array}$ \\
\hline Africa & $\begin{array}{r}0.098 \\
(0.131)\end{array}$ & $\begin{array}{l}0.173^{*} \\
(0.086)\end{array}$ & $\begin{array}{l}0.228 * \\
(0.050)\end{array}$ & $\begin{array}{c}0.176 * \\
(0.078)\end{array}$ & $\begin{array}{l}0.240 * * \\
(0.0480)\end{array}$ \\
\hline Intercept & $\begin{array}{l}-4.82 * * \\
(0.819) \\
\end{array}$ & $\begin{array}{r}-5.01 * \\
(0.144) \\
\end{array}$ & $\begin{array}{r}-5.25 * \\
(0.243) \\
\end{array}$ & $\begin{array}{r}-4.98 * \\
(0.081) \\
\end{array}$ & $\begin{array}{l}-5.20 \text { ** } \\
(0.147) \\
\end{array}$ \\
\hline $\begin{array}{l}\text { Country N } \\
\text { R-squared }\end{array}$ & $\begin{array}{r}45 \\
0.405\end{array}$ & $\begin{array}{r}45 \\
0.413\end{array}$ & $\begin{array}{r}45 \\
0.438\end{array}$ & $\begin{array}{r}45 \\
0.414\end{array}$ & $\begin{array}{r}45 \\
0.440\end{array}$ \\
\hline
\end{tabular}

**indicates significant at .05 level, *indicates significant at .10 level; ${ }^{\wedge}$ indicates joint significance of f-test. 
Table 2

FDI and Bilateral Investment Treaties: Fixed Effects Model (1980-2000)

Run: BITs signed with

High income

Run: BITs signed with

low income

Run: BITs signed with

Total

Natural log GDP per capita

Political Risk

Risk*Total BITs
2

\begin{tabular}{|c|c|}
\hline 3 & 4 \\
\hline 0.0181 & -0.128 \\
\hline$(0.024)$ & $(0.147)$ \\
\hline $\begin{array}{r}-0.0155 \\
(0.0306)\end{array}$ & $\begin{array}{r}0.124 \\
(0.189)\end{array}$ \\
\hline
\end{tabular}

Risk*lowincome BITs

$-0.00265$

(0.00353)

Risk*highincome BITs

(0.00307)

Black Market Premium

$\begin{array}{lll}0.00154 & 0.00182 & 0.00190\end{array}$

0.00131

0.00119

(0.00227)

(0.0021)

(0.00212)

$(0.00231)$

(0.00243)

Natural log Population

$$
0.170 \text { * }
$$

$0.167 *$

$0.167^{*}$

$0.171 *$

$(0.0646) \quad(0.0692)$

(.0693)

(0.0677)

$0.171 *$ $(0.0687)$

Growth

$$
-0.012 \quad-0.0116
$$$$
-0.0119
$$

$-0.0105$

$$
(0.0137) \quad(0.0135)
$$

(0.0136)

(0.0146)

\begin{tabular}{|c|c|c|c|c|c|}
\hline & $*$ & $*$ & $*$ & & \\
\hline Intercept & $\begin{array}{l}-4.05 * \\
(1.43)\end{array}$ & $\begin{array}{c}-4.49 * \\
(1.47)\end{array}$ & $\begin{array}{c}-4.52 * \\
(1.47)\end{array}$ & $\begin{array}{r}-4.39 * * \\
(1.58)\end{array}$ & $\begin{array}{l}-4.36 \\
(1.63)\end{array}$ \\
\hline Country N & 46 & 46 & 46 & 46 & 46 \\
\hline R-squared & 0.340 & 0.341 & 0.343 & 0.347 & 0.352 \\
\hline Root MSE & 0.538 & 0.538 & 0.5405 & 0.5405 & 0.5410 \\
\hline
\end{tabular}

(0.0152)

Natural Resources

**indicates significant at .05 level, *indicates significant at .10 level; ^ indicates joint significance of f-test. 
Both of our models clearly demonstrate the importance of GDP per capita, political risk, and population or market size for determining FDI. Although the coefficients on political risk and GDP appear small, it is important to remember that average FDI inflows as a percentage of world inflows for the countries in our sample is 0.20 percent. In both of our base specifications, we find a positive and significant relationship between GDP per capita and FDI inflows, controlling for the remaining determinants of FDI. Specifically, in our fixed effects model, a one-percent increase in GDP per capita leads to a 0.19 percent increase in a country's share of total world FDI, while in our random effects model that equates to a 0.13 percent increase. Similarly, political risk has a significant and positive effect on FDI in our base case, with a one unit increase in the political risk scale (equating to an improvement in political risk) equating to a .01 percent increase in the share of a country's FDI inflows as a percentage of world inflows, in both models. Likewise, an increase of 1 percent in the population of a country, on average, equates to an increase of 17\% in a county's share of world FDI from our fixed effects model, and this share is even greater in the random effects model.

The remaining variables in our fixed effects model appear to have no effect on FDI. When we add BITs into the model, the basic results remain the same, with BITs having a positive relationship with FDI inflows. ${ }^{29}$ However, the only point where this relationship is statistically significant is the joint significance of the treties in their interaction with political risk. Thus, for our analysis, column four in tables 1 and 2 is the most interesting. In our random effects model, only the continent indicators of our time invariant variables retain significance through all of the models. The joint effect of BITs and BITs interacted with political risk proved to be significant at the .05 significance level. This enables us to consider whether BITs may have different effects on countries depending on their level of political risk. ${ }^{30}$ By interacting the cumulative total number of BITs signed with political risk, table 3 shows that as political risk goes down (increases in the actual indicator) the conditional effect of an additional BIT on FDI decreases. In other words, as countries become less risky, BITs do less to attract FDI. This is what we would expect if BITs were basically identical across countries. They should have more of a marginal effect on countries that are relatively risky.

Thus, the number of BITs signed appears to have little impact on a country's ability to attract FDI. However, there does appear to be an interaction between the level of political risk and property rights protection. Countries that are relatively risky seem to be able to attract somewhat more FDI by signing BITS. For those that are relatively safe for investors the marginal effect of BITs is small. Of course, because the data do not include either very risky or very safe countries, we are much more confident of our findings for the middle range of countries in our data set.

\footnotetext{
${ }^{29}$ We estimated the model in three ways, just looking at BITs signed with high income countries, separating out high and low income BITs, and finally the cumulative total of BITs. The results were robust to all three specifications, so we retain the cumulative total. Additionally, we separated out US BITs from the cumulative total of BITs and the estimates revealed that having signed a US BIT actually decreases a country's share of world FDI by two percent.

${ }^{30}$ This analysis failed to present significant results in both columns four and five of the fixed effects model and column five of the random effects model. The following analysis refers to column four of table .
} 
Table 3

Effects of BITs on FDI Conditional on Political Risk

\begin{tabular}{|c|c|c|c|c|}
\hline Range of PR & $\begin{array}{l}\text { Conditional } \\
\text { effects of } \\
\text { BITs on } \\
\text { FDI } \\
\end{array}$ & $\begin{array}{c}\text { Standard } \\
\text { error of } \\
\text { conditional } \\
\text { effect } \\
\end{array}$ & $\begin{array}{c}\mathrm{t} \text { statistics of } \\
\text { conditional } \\
\text { effect }\end{array}$ & $\begin{array}{c}\text { Countries } \\
\text { with avg. } \\
\text { in range }\end{array}$ \\
\hline 0 (high risk) & 0.036 & 0.019 & 1.89 & \\
\hline 5 & 0.035 & 0.017 & 2.03 & \\
\hline 10 & 0.034 & 0.015 & 2.21 & \\
\hline 15 & 0.033 & 0.014 & 2.44 & \\
\hline 20 & 0.032 & 0.012 & 2.73 & \\
\hline 25 & 0.031 & 0.01 & 3.13 & \\
\hline 30 & 0.03 & 0.008 & 3.67 & \\
\hline 35 & 0.029 & 0.007 & 4.43 & 1 \\
\hline 40 & 0.028 & 0.005 & 5.47 & 3 \\
\hline 45 & 0.027 & 0.004 & 6.56 & 7 \\
\hline 50 & 0.026 & 0.004 & 6.66 & 4 \\
\hline 55 & 0.025 & 0.005 & 5.43 & 9 \\
\hline 60 & 0.024 & 0.006 & 4.06 & 9 \\
\hline 65 & 0.023 & 0.007 & 3.06 & 5 \\
\hline 70 & 0.022 & 0.009 & 2.37 & 4 \\
\hline 75 & 0.021 & 0.011 & 1.88 & \\
\hline 80 & 0.019 & 0.013 & 1.53 & \\
\hline 85 & 0.018 & 0.015 & 1.26 & \\
\hline 90 & 0.017 & 0.016 & 1.05 & \\
\hline 95 & 0.016 & 0.018 & 0.89 & \\
\hline 100(low risk) & 0.015 & 0.02 & 0.75 & \\
\hline
\end{tabular}




\section{Bilateral Analysis}

The most comprehensive source for FDI data is the "U.S. International Transactions Accounts Data," produced yearly by the United States Bureau of Economic Analysis (BEA). ${ }^{31}$ The data comprise two broad areas covering all US FDI operations from 1950 through the present. The BEA reports balance of payments and direct investment data on transactions between US parents and their foreign affiliates abroad, and financial and operating data covering the foreign operations of US-based multinational corporations. The BEA's data generally conform to international reporting standards and are available with substantial country and industry detail. Thus, for understanding the bilateral relationship between FDI inflows and BITs, the BEA data would seem ideal. Unfortunately, it is available only for MNCs based in the United States. According to the United Nations Conference on Trade and Development (UNCTAD) database on FDI, US-based MNCs accounted for only twelve percent of outward world FDI flows in 2000 and 21 per cent of FDI outward stock. Further, more than half of U.S. FDI is directed towards the European Union. Nevertheless, the breadth and quality of the BEA data give a strong indication of the relationship between US BITs and US FDI flows (Mataloni 1995, Quijano 1990, Lipsey 2001, and UNCTAD 2001).

We measure FDI flows as capital inflows (outflows(-)) from the United States in millions of US dollars. In this case, we are interested in changes in overall US capital stock into or out of a country as a result of signing a BIT with the US. In other words, we care only about how signing a BIT with the US affects US FDI flows to that specific country. FDI flows are the best indicator of yearly changes in US capital stock in our countries of interest. Our BIT variable is a dummy equal to 1 in the year that a BIT was signed between the host country and the US and each year thereafter and a 0 for countries without US BITs.

In addition to the variables used in the general analysis, we include a measure of distance between the US and the host country government in our pooled data analysis. Distance serves as a proxy for the transport and trade costs that affect the firm's decision to invest, and thus we assume that the greater the distance between a host country and the US, the lower the probability of US investment. Further, to account for the bilateral nature of the flows, we include a measure of exchange rate stability of the host country, as well a variable to measure the difference in average years of schooling between the US and the host country to proxy for skill differences between the host and investing country. Theoretical analysis posits that the greater the difference in skill level between countries, the lower the level of investment (Carr et al 2002). Specifically, we use the difference in total mean years of education between the United States and the host country as our measure of skill difference. Theoretically, exchange rate levels and stability have an important influence on FDI flows, but their impact is ambiguous. Exchange rate stability could increase investment in low productivity investment or investment for production in the local market, while decreasing investment in industries with high entry costs or investment tended for re-export (Bénassy-Quéré et al 1999).

The endogeneity problem in our general model does not seem to be a concern in the case of US FDI flows. Blonigen and Davies(2001), in their work on bilateral tax treaties with the US, point

\footnotetext{
31 The BEA's U.S. International Transactions Accounts Data is available on line for interactive analysis at: http://www.bea.doc.gov/bea/di/di1fdibal.htm
} 
out that the U.S. does not limit BITs only to countries that have high FDI activity. Appendix G demonstrates that there is no correlation between the levels of inflows of US FDI and the date that the treaty was signed. In fact, in many cases, the US has signed treaties with host countries with very low FDI inflows. Thus, we do not need to control for endogeneity in our estimates.

We again model the data using pooled and fixed effects analysis. Our model specifications are identical to those used above, except that we include a time trend in this case. Data limitations necessitated year-to-year changes rather than observing means over five year periods as in the general analysis. Our first two models lag only GDP per capita and growth, while our second two models lag all economic variables to account for greater changes over time.

Our results from this more detailed analysis are interesting and counter-intuitive in many cases. Two of our most interesting results are the negative coefficients on both BITs and political risk, indicating that countries that have signed a BIT or have a BIT with the US in place are likely to have significantly lower FDI flows. Likewise, the negative sign on political risk indicates that as the political risk indicator increases (equating to a less risky environment), FDI flows from the US also decrease. Again, this runs counter to our intuition and accepted evidence on political risk, and so we must look to the interaction between political risk and the BIT, which while insignificant by itself, is significant at the $95 \%$ confidence level for all the regressions for joint significance of BITs and political risk.

When we look at the conditional effect of the interaction, we observe an effect opposite to what we saw in our general analysis. For US BITs, we see that as political risk goes down (increases in the actual indicator), the conditional effect of signing a BIT with the US actually increases conditional FDI inflows. In other words, as countries become less risky, a BIT with the US actually aids in attracting greater FDI inflows from the US. Unfortunately, we can only be certain of this outcome at very high levels of political risk.

The negative sign on openness is not completely surprising. The results tell us that the more open a country's economy, the lower the inflows of US investment. This could be a result of investment for the host country market, where more closed economies advantage the investor. GDP, time, education, and population all fit with our intuitive reasoning. GDP and population, our proxies for market size, both agree with theoretical reasoning that the greater the market size, the larger the size of FDI inflows. US outflows of FDI continue to increase yearly, and so it is not surprising that FDI flows increase along with time. The coefficient on distance indicates that the further a country is from the United States, the lower the level of investment flows to that country, though this variable remains statistically insignificant from zero in the equations. Finally, the greater the difference in education levels between the US and the host country, the lower the level of FDI flows.

Overall, these results indicate that signing a BIT with the US does not correspond to increased FDI inflows. Additionally, it does not appear that the US BIT alleviates political risk factors for investors based in the US. 
Table 4

FDI and Bilateral Investment Treaties:

Bilateral Relationship with the United States (1980-2000)

\begin{tabular}{|c|c|c|c|c|c|c|c|c|}
\hline \multirow{2}{*}{ BIT signed } & \multicolumn{4}{|c|}{ GDP lag } & \multicolumn{4}{|c|}{ All lag } \\
\hline & \multirow{2}{*}{$\begin{array}{l}\text { Random } \\
\begin{array}{r}-408.51 \\
(301.96)\end{array}\end{array}$} & \multicolumn{3}{|c|}{ Fixed Effects } & \multirow{2}{*}{$\begin{array}{r}\text { Random } \\
-370.01 \\
(339.33)\end{array}$} & \multicolumn{3}{|c|}{ Fixed Effects } \\
\hline with US & & & $\begin{array}{l}-477.97 \\
(208.07)\end{array}$ & $* *$ & & & $\begin{array}{l}-463.71 \\
(195.50)\end{array}$ & $* * *$ \\
\hline $\begin{array}{l}\text { Ln GDP per } \\
\text { capita }\end{array}$ & $\begin{array}{l}223.02 \\
(82.28)\end{array}$ & $* * *$ & $\begin{array}{r}49.41 \\
(187.92)\end{array}$ & & $\begin{array}{l}266.73 \\
(81.44)\end{array}$ & $* * *$ & $\begin{array}{r}120.02 \\
(191.63)\end{array}$ & \\
\hline Political Risk & $\begin{array}{r}-9.47 \\
(3.08)\end{array}$ & $* * *$ & $\begin{array}{l}-10.65 \\
(3.29)\end{array}$ & $* * *$ & $\begin{array}{l}-7.19 \\
(3.26)\end{array}$ & $* *$ & $\begin{array}{l}-9.45 \\
(2.91)\end{array}$ & $* * *$ \\
\hline $\begin{array}{l}\text { Risk*Total } \\
\text { BITs }\end{array}$ & $\begin{array}{r}4.39 \\
(4.84)\end{array}$ & & $\begin{array}{r}6.03 \\
(3.31)\end{array}$ & $*$ & $\begin{array}{r}4.15 \\
(5.74)\end{array}$ & & $\begin{array}{r}6.58 \\
(3.41)\end{array}$ & $* *$ \\
\hline Growth & $\begin{array}{r}298.77 \\
(225.23)\end{array}$ & & $\begin{array}{r}352.14 \\
(176.85)\end{array}$ & $* *$ & $\begin{array}{r}240.91 \\
(237.42)\end{array}$ & & $\begin{array}{r}284.56 \\
(178.09)\end{array}$ & \\
\hline Population & $\begin{array}{r}0.00063 \\
(0.00032)\end{array}$ & $*$ & $\begin{array}{r}0.0025 \\
(0.0016)\end{array}$ & $*$ & $\begin{array}{r}.00066 \\
(.00030)\end{array}$ & $* *$ & $\begin{array}{r}0.0029 \\
(0.0019)\end{array}$ & \\
\hline $\begin{array}{l}\text { Natural } \\
\text { Resources }\end{array}$ & $\begin{array}{r}-1.81 \\
(1.64)\end{array}$ & & $\begin{array}{r}-3.20 \\
(2.09)\end{array}$ & & $\begin{array}{r}-1.69 \\
(1.66)\end{array}$ & & $\begin{array}{r}-3.37 \\
(1.94)\end{array}$ & $*$ \\
\hline Openness & $\begin{array}{l}-2.89 \\
(1.34)\end{array}$ & $* *$ & $\begin{array}{r}-2.20 \\
(1.35)\end{array}$ & $*$ & $\begin{array}{r}-3.41 \\
(1.34)\end{array}$ & $* *$ & $\begin{array}{r}-2.64 \\
(1.32)\end{array}$ & $* *$ \\
\hline $\begin{array}{l}\text { Exchange Rate } \\
\text { Stability }\end{array}$ & $\begin{array}{r}0.082 \\
(0.057)\end{array}$ & & $\begin{array}{r}0.09 \\
(0.10)\end{array}$ & & $\begin{array}{r}0.25 \\
(0.19)\end{array}$ & & $\begin{array}{r}0.44 \\
(0.48)\end{array}$ & \\
\hline Skill Difference & $\begin{array}{r}-58.53 \\
(40.50)\end{array}$ & & $\begin{array}{l}-236.64 \\
(72.01)\end{array}$ & $* * *$ & $\begin{array}{r}-31.92 \\
(35.66)\end{array}$ & & $\begin{array}{l}-247.05 \\
(77.92)\end{array}$ & $* * *$ \\
\hline Time Counter & $\begin{array}{r}51.97 \\
(6.46)\end{array}$ & $* * *$ & $\begin{array}{l}40.54 \\
(9.35)\end{array}$ & $* * *$ & $\begin{array}{l}50.86 \\
(7.02)\end{array}$ & $* * *$ & $\begin{array}{l}36.60 \\
(8.82)\end{array}$ & $* * *$ \\
\hline Distance & $\begin{array}{l}-0.020 \\
(0.026)\end{array}$ & & & & $\begin{array}{l}-0.02 \\
(0.02)\end{array}$ & & & \\
\hline Constant & $\begin{array}{r}-103646.6 \\
(12891.86) \\
\end{array}$ & $* * *$ & $\begin{array}{r}-78501.74 \\
(18152.41) \\
\end{array}$ & $* * *$ & $\begin{array}{r}-102062.1 \\
(14037.81) \\
\end{array}$ & $* * *$ & $\begin{array}{r}-71163.91 \\
(17131.32) \\
\end{array}$ & $* * *$ \\
\hline $\begin{array}{l}\text { Countries } \\
\text { Observations } \\
\text { R-Squared }\end{array}$ & $\begin{array}{r}54 \\
667 \\
0.17\end{array}$ & & $\begin{array}{r}54 \\
667 \\
0.59\end{array}$ & & $\begin{array}{r}0 \\
0 \\
0.18\end{array}$ & & $\begin{array}{r}54 \\
622 \\
0.61\end{array}$ & \\
\hline
\end{tabular}




\section{B. Private Domestic Investment}

We estimate the determinants of private domestic investment in a similar manner to our model of FDI except that the dependent variable is measured in per capita terms. We build on the literature on the determinants of private investment in developing countries ${ }^{32}$. Market size, proxied by GDP per capita, and growth rates of the country are again theorized to be the primary determinants of investment. The financial depth or overall size of the financial sector of a country is also likely to be an important determinant. We proxy financial depth with a measure of liquid liabilities. The hypothesis is that the greater the size of the financial sector in a country, the more investment we should see. As in the FDI regression, we exclude taxes and inflation. ${ }^{33}$ As with FDI, political risk is likely to be an important determinant of private investment. Finally, we include continent and latitude as country-specific effects.

Private domestic investment is defined as the difference between total gross domestic investment (from national accounts) and consolidated public investment. The variable is the ratio of domestic private investment to GDP. The ratios are computed using local currency units at current prices, readily available from the World Bank's World Development Indicators.

Aside from differences in variables, we model private investment identically to our FDI specification.

\footnotetext{
32 There are a number of good overviews of the determinants of private investment in developing countries. See for example, Schmidt-Hebbel et al (1996), Wai, and Wong (1982), and Ndikumana (2001).

${ }^{33}$ Robustness checks again resulted in coefficients of zero with no statistical significance and no change to the remaining estimates.
} 
Table 5

Private Investment and Bilateral Investment Treaties: Random Effects Model (1980-2000)

\begin{tabular}{|c|c|c|c|c|}
\hline & Base Case & 2 & 3 & 4 \\
\hline BITs signed with & & & $0.34 * *$ & \\
\hline High income & & & $(0.13)$ & \\
\hline BITs signed with & & & $-0.29 * *$ & \\
\hline Low income & & & $(0.09)$ & \\
\hline Total BITs & & $\begin{array}{r}-0.05 \\
(0.04)\end{array}$ & & $\begin{array}{l}0.53 * * \\
(0.26)\end{array}$ \\
\hline Natural log GDP per capita & $\begin{array}{l}2.08 * * \\
(0.68)\end{array}$ & $\begin{array}{l}1.96 \text { ** } \\
(0.68)\end{array}$ & $\begin{array}{l}2.13 \text { ** } \\
(0.68)\end{array}$ & $\begin{array}{l}2.08 * * \\
(0.69)\end{array}$ \\
\hline Political Risk & $\begin{array}{r}0.03 \\
(0.03)\end{array}$ & $\begin{array}{r}0.05 \\
(0.04)\end{array}$ & $\begin{array}{r}0.03 \\
(0.04)\end{array}$ & $\begin{array}{l}0.08 * * \\
(0.04)\end{array}$ \\
\hline Risk*Total BITs & & & & $\begin{array}{r}-0.01 \\
(0.01)\end{array}$ \\
\hline Liquid Liabilities & $\begin{array}{r}0.04 \\
(0.03)\end{array}$ & $\begin{array}{r}0.04 \\
(0.03)\end{array}$ & $\begin{array}{r}0.04 \\
(0.03)\end{array}$ & $\begin{array}{r}0.05 \\
(0.03)\end{array}$ \\
\hline Growth & $\begin{array}{r}-0.05 \\
(0.14)\end{array}$ & $\begin{array}{r}-0.05 \\
(0.14)\end{array}$ & $\begin{array}{l}-0.05 \\
(0.13)\end{array}$ & $\begin{array}{r}-0.06 \\
(0.13)\end{array}$ \\
\hline Natural Resources & $\begin{array}{l}-0.05 * * \\
(0.02)\end{array}$ & $\begin{array}{l}-0.05 * * \\
(0.02)\end{array}$ & $\begin{array}{l}-0.05 * * \\
(0.02)\end{array}$ & $\begin{array}{l}-0.05 * * \\
(0.02)\end{array}$ \\
\hline Time Counter & $\begin{array}{r}0.50 \\
(0.32)\end{array}$ & $\begin{array}{l}0.93 \text { ** } \\
(0.36)\end{array}$ & $\begin{array}{l}0.78 \text { ** } \\
(0.35)\end{array}$ & $\begin{array}{l}0.79 * * \\
(0.37)\end{array}$ \\
\hline Latitude & $\begin{array}{l}-13.63 * * \\
(4.53)\end{array}$ & $\begin{array}{l}-12.76 \text { ** } \\
(4.58)\end{array}$ & $\begin{array}{l}-12.46 * * \\
(4.58)\end{array}$ & $\begin{array}{l}-13.91 \text { ** } \\
(4.64)\end{array}$ \\
\hline Latin America & $\begin{array}{l}-3.90 * * \\
(1.39)\end{array}$ & $\begin{array}{l}-4.14 * * \\
(1.41)\end{array}$ & $\begin{array}{l}-3.70 * * \\
(1.41)\end{array}$ & $\begin{array}{r}-3.74 \\
(1.43)\end{array}$ \\
\hline Africa & $\begin{array}{l}-7.68 * * \\
(1.66)\end{array}$ & $\begin{array}{l}-8.21 \text { ** } \\
(1.71)\end{array}$ & $\begin{array}{l}-7.76 * * \\
(1.71)\end{array}$ & $\begin{array}{c}-7.77 \\
(1.73)\end{array}$ \\
\hline Intercept & $\begin{array}{r}1.12 \\
(4.33)\end{array}$ & $\begin{array}{r}1.07 \\
(4.33)\end{array}$ & $\begin{array}{c}-0.22 \\
(4.34)\end{array}$ & $\begin{array}{r}-1.54 \\
(4.51)\end{array}$ \\
\hline Country N & 40 & 40 & 40 & 40 \\
\hline R-squared & 0.410 & 0.416 & 0.446 & 0.426 \\
\hline
\end{tabular}

**indicates significant at .05 level, *indicates significant at .10 level; ${ }^{\wedge}$ indicates joint significance of f-test. 


\section{TABLE 6}

Private Investment and Bilateral Investment Treaties:

\begin{tabular}{|c|c|c|c|c|}
\hline & Base Case & 2 & 3 & 4 \\
\hline BITs signed with & & & $0.43 * *$ & \\
\hline high income & & & $(0.19)$ & \\
\hline BITs signed with & & & $-0.31 * *$ & \\
\hline low income & & & $(0.13)$ & \\
\hline \multirow[t]{2}{*}{ Total BITs } & & 0.003 & & $0.45 *$ \\
\hline & & $(0.044)$ & & $(0.25)$ \\
\hline \multirow[t]{2}{*}{ Natural log GDP per capita } & $1.6 * *$ & $1.6 * *$ & $1.84 * *$ & $1.67 * *$ \\
\hline & $(0.63)$ & $(0.63)$ & $(0.6)$ & $(0.62)$ \\
\hline \multirow[t]{2}{*}{ Political Risk } & 0.02 & 0.02 & 0.01 & 0.05 \\
\hline & $(0.05)$ & $(0.05)$ & $(0.05)$ & $(0.05)$ \\
\hline \multirow[t]{2}{*}{ Risk*Total BITs } & & & & $-0.01 *$ \\
\hline & & & & $(0.01)$ \\
\hline \multirow[t]{2}{*}{ Liquid Liabilities } & $0.07 * *$ & $0.07 * *$ & $0.06 * *$ & $0.07 * *$ \\
\hline & $(0.03)$ & $(0.03)$ & $(0.03)$ & $(0.03)$ \\
\hline \multirow[t]{2}{*}{ Growth } & -0.06 & -0.07 & -0.05 & -0.07 \\
\hline & $(0.12)$ & $(0.12)$ & $(0.11)$ & $(0.12)$ \\
\hline \multirow[t]{2}{*}{ Time Counter } & 0.52 & 0.64 & 0.64 & 0.58 \\
\hline & $(0.38)$ & $(0.46)$ & $(0.43)$ & $(0.46)$ \\
\hline \multirow[t]{2}{*}{ Intercept } & -2.33 & -2.32 & -4.4 & -4.69 \\
\hline & $(4.97)$ & $(5.23)$ & $(5.01)$ & $(5.4)$ \\
\hline Country N & 40 & 40 & 40 & 40 \\
\hline R-squared & 0.21 & 0.21 & 0.27 & 0.23 \\
\hline Root MSE & 4.39 & 4.41 & 4.28 & 4.39 \\
\hline
\end{tabular}

**indicates significant at .05 level, *indicates significant at .10 level; ${ }^{\wedge}$ indicates joint significance of f-test. 
In both of our specifications, market size appears to be the most significant determinant of private investment. Specifically, an increase of one percent in GDP per capita increases private investment over GDP by approximately two percent in both of our models. Our fixed effects model posits that for every one percent increase of liquid liabilities in the economy, private investment increases by .07 percent. This is not true in our random effects model, where our coefficient estimate is not significantly different from zero. The importance of natural resources has a negative impact on domestic investment in the random effects model. We omitted natural resources from our fixed effects regression, as they had little impact on the remainder of the model and would be accounted for in the country fixed effects. In our random effects model, we are able to view some of the country specific effects. For example, the closer a country is to the equator, the lower the level of private investment in the economy. Latin America and Africa have lower levels of investment then do the countries of Eastern Europe and the Soviet Union.

In both cases, BITs have a significant effect on investment. Although the individual coefficients on the interaction between separated BITs and political risk were insignificant, an F-test of the joint significance of all four coefficients was positive at the 0.05 level. Specifically, for each additional BIT signed with a high-income country, private domestic investment increases on average by .34 percent. At the same time, for each additional BIT signed with a low-income country, private investment decreases by about .29 percent. These results were nearly identical in both of our models.

In the fixed effects model, adding BITs together produced a significant effect on private investment when interacted with political risk, and this enables us to carry out the same exercise as with FDI. We see that as political risk goes down (increases in the actual indicator), the conditional effect of an additional BIT on domestic investment falls actually becoming negative in the range of 70-100 (table 7). In other words, as countries become less risky, the number of BITs in force appears to discourage domestic investment. We cannot tell from this exercise why this occurs, but one explanation is that the FDI that is encouraged by BITs is crowding out domestic investment in spite of the rather good politicalllegal environment. In contrast, at high levels of risk, BITs may encourage FDI that takes the form of joint ventures with local firms. Thus, BITs seem to have a positive relationship to private investment in developing countries except when political risk is low. Although we would like to know the type of investment they encourage, that is not possible from the available data. 


\section{Table 7}

Effects of BITs on Private Investment Conditional on Political Risk

\begin{tabular}{|c|c|c|c|c|}
\hline Range of PR & $\begin{array}{c}\text { Conditional } \\
\text { effects of } \\
\text { BITs on } \\
\text { FDI } \\
\end{array}$ & $\begin{array}{c}\text { Standard } \\
\text { error of } \\
\text { conditional } \\
\text { effect }\end{array}$ & $\begin{array}{c}\text { t statistics of } \\
\text { conditional } \\
\text { effect }\end{array}$ & $\begin{array}{c}\text { Countries } \\
\text { with avg. } \\
\text { in range }\end{array}$ \\
\hline 0 (high risk) & 0.53 & 0.25 & 2.16 & \\
\hline 5 & 0.49 & 0.23 & 2.16 & \\
\hline 10 & 0.45 & 0.21 & 2.15 & \\
\hline 15 & 0.41 & 0.19 & 2.15 & \\
\hline 20 & 0.37 & 0.17 & 2.14 & \\
\hline 25 & 0.32 & 0.15 & 2.13 & \\
\hline 30 & 0.28 & 0.13 & 2.12 & \\
\hline 35 & 0.24 & 0.11 & 2.11 & 1 \\
\hline 40 & 0.20 & 0.10 & 2.09 & 3 \\
\hline 45 & 0.16 & 0.08 & 2.06 & 7 \\
\hline 50 & 0.12 & 0.06 & 1.99 & 4 \\
\hline 55 & 0.08 & 0.04 & 1.86 & 9 \\
\hline 60 & 0.04 & 0.03 & 1.44 & 9 \\
\hline 65 & 0.00 & 0.02 & -0.25 & 5 \\
\hline 70 & -0.05 & 0.02 & -1.91 & 4 \\
\hline 75 & -0.09 & 0.04 & -2.18 & \\
\hline 80 & -0.13 & 0.06 & -2.23 & \\
\hline 85 & -0.17 & 0.08 & -2.23 & \\
\hline 90 & -0.21 & 0.09 & -2.23 & \\
\hline 95 & -0.25 & 0.11 & -2.23 & \\
\hline 100 (low risk) & -0.29 & 0.13 & -2.23 & \\
\hline
\end{tabular}

The results obtained when separating BITs out by home country economy need further explanation. There could be a number of reasons, both positive and negative for the observed positive relationship between private investment and BITs with high income countries. We can think of two possible alternatives. If the treaties stimulated FDI, this positive result could be the consequence of positive spillovers from foreign investment. However, our results in the prior section on FDI suggest that this is not happening as a share of total FDI. Alternatively, this result could indicate increased investment from the existing domestic business class, more confident in the maintenance of the property rights status quo. The negative result on BITs signed with developing economies could be the result of increased investment and competition from neighboring countries substituting for existing domestic investment. These results suggest that it is important to see if any relationship exists between BITs and property rights. Our results are preliminary, but give us an approximation of the relationship. 


\section{Property Rights}

Our final estimation is a first attempt to look at the effect of BITs on property rights. To estimate the effect of BITs on property rights, we again begin with the base specification of determinants of property rights other than BITs. This model is difficult to specify given the subjective nature of the available measures of property rights. A number of qualitative statistics exist, as well as proxy measures such as credit to the private sector as a percentage of GDP. Proxy measures generally correlate highly with investment. We operationalize property rights as a combination of a series of factors from the ICRGs political risk rating (used in the earlier analyses). Specifically, we combine the four indicators that ought to have the strongest effect on an investor's decision to invest in his property: the investment profile of a country (measured as a combination of the viability of contracts, probability of expropriation, and the ability to repatriate profits), its level of law and order, and its level of corruption.

Although a great deal of evidence exists on the effects of property rights on economic growth and stability, the determinants of strong property rights are hard to estimate. Measures of economic growth and government stability will likely serve as the primary determinants of property rights. However, although these factors may influence the strength of property rights in a country, stronger property rights will also have a positive influence on economic factors. We also include a variable for socio-economic indicators of the population drawn from the ICRG dataset. We account for overall social conditions through ICRG's composite index that measures conditions that may constrain government action, unemployment, consumer confidence and poverty. Finally, we include natural resources as likely determinants of property rights. Although higher levels of natural resources could have a positive effect on FDI inflows, their effect on property rights should be zero or negative. As our above results indicate, poor protection of property rights discourages FDI. However, countries with higher levels of natural resources should have less need to protect property rights because FDI will flow towards natural resources regardless of the property rights regime. However, our own results results, reported above did not find natural resource endowments to be a significant determinant of FDI.

We employ an independent variable, fixed-effects time series model with panel corrected standard errors. In this case we have a larger sample size with greater variation across time than in our prior estimations. (We also ran the random effects model, but came up with nearly identical results.) We instrument for economic growth factors with lagged values of the regressors to limit inconsistency arising from simultaneity bias. The model is identical to our earlier fixed effects regressions with instrumental variables except that some of the included variables are different. 


\section{Table 8}

Property Rights and Bilateral Investment Treaties (1980-2000)

\begin{tabular}{lrr} 
& Base Case & 2 \\
\hline Run: BITs signed with & 0.004 \\
high income & $(0.05)$ \\
& \\
Run: BITs signed with & 0.03 \\
low income & $(0.02)$
\end{tabular}

Run: BITs signed with

0.02

Total

$(0.01)$

Natural log GDP per capita

$$
0.68 * *
$$

$0.65^{* *}$

$0.65 * *$

$$
(0.19)
$$

$(0.19)$

$(0.19)$

Growth

$\begin{array}{rrr}-0.002 & -0.005 & -0.005 \\ (0.024) & (0.025) & (0.025)\end{array}$

Natural Resources

$$
-0.01
$$

$-0.01$

$-0.01$

(0.01)

(0.01)

(0.01)

Socio economic indicator

$\begin{array}{ccc}1.09^{* *} & 1.06^{* *} & 1.06^{* *} \\ (0.11) & (0.11) & (0.11)\end{array}$

Time Counter

$\begin{array}{ccc}0.88 * * & 0.77 * * & 0.78 * * \\ (0.11) & (0.12) & (0.13)\end{array}$

Intercept

$$
-4.85 * *
$$

$-3.96 * *$

Country N

68

68

R-squared

0.550

0.557

0.558

Root MSE

1.875

1.864

1.866 
In our base case, we find that GDP per capita, our indicator of the socioeconomic structure, and time are the primary determinants of property rights. Growth and natural resources do not have statistically significant results in any of our regressions. The negative sign on natural resources is interesting, but may simply be a result of resource rich countries tending to have political systems with weaker institutions. Specifically, we find that an increase of one percent in GDP per capita leads to an increase of .68 on the property rights scale. Similarly, an increase of 1 in the socio-economic indicator leads to an increase of one in the property rights scale, and for every additional 5 year period, property rights increase by .88. Adding BITs to our model had no apparent effect on the results. Perhaps the most interesting result is the importance of time for improving property rights. Although some of the time effect may reflect the effects of BITs, it is interesting to note that in general, countries tend to be moving towards greater protection of property rights, all else equal. Thus, from this preliminary specification we cannot say that BITs have any significant effect on domestic property rights. There do not seem to be spillovers, either negative or positive, on domestic institutions.

\section{Conclusions}

With the advent of BITs, foreign investors are assured of a strong, binding property rights system outlined in international or industrialized country law. Local players in the business sector, however, are left with the often-unstable property rights system of their home country. When foreign investors can able bypass local law and lower their risk through BITs, developing country governments may have lost a major incentive to strengthen their domestic property rights regimes. Thus BITs can have both costs and benefits for emerging economies. Our analysis takes a first step towards understanding the conflicting impacts of BITs on the domestic business environment.

Overall, we conclude that the relationship between BITs and FDI is weak. In general, BITs appear to have little impact on FDI. Likewise, we find little relationship between the existence of a BIT with the United States and the level of US FDI. Where there is a relationship, it is weakly negative. However, BITs are not always ineffectual. Indeed, when countries are relatively risky, we find that BITs do attract greater amounts of FDI. This indicates that one of the major reasons for signing BITs, decreasing the risk of property rights infringement for foreign investors, may indeed be fulfilled. BITs, therefore, appear to be important instruments for riskier countries that wish to attract FDI, but, in general, they may not fulfill their major objective.

Analyzing the relationship between BITs and the domestic investment environment is important because we seek to understand whether the treaties might be disadvantageous for domestic investors. We found that such disadvantages might arise in countries where political risk is low. However, these are countries where BITs do not play a very significant role. Overall, however, there seems to be a positive relationship between BITs and private domestic investment. Thus, although the treaties may advantage foreign investors over domestic investors, they do not appear to dampen domestic investment. Furthermore, although our analysis is preliminary, no relationship seems to exist, either positive or negative, between BITs and domestic property rights. 
The reasons behind stalled reform and weak law enforcement in developing countries are numerous, and BITs are certainly not the primary cause. At the same time, it appears that a tool designed to reduce risk and increase foreign investment to low and middle-income countries has no impact on the overall investment environment. Signing BITs with high-income countries does seem to have a positive impact on private domestic investment, but the causation does not flow through the domestic legal environment. Instead, the effect may reflect joint ventures or other direct spillovers from FDI for local entrepreneurs. BITs may even limit domestic investment in countries with relatively good institutions perhaps by crowding out local investors. Obviously, much work needs to be done to assess the repercussions of BITs. Further work needs to disaggregate investment decisions to see if different types of FDI are more or less affected by BITs and, perhaps more importantly, to determine if differences in the content of BITs affect the overall business environment. 
Figure 1a

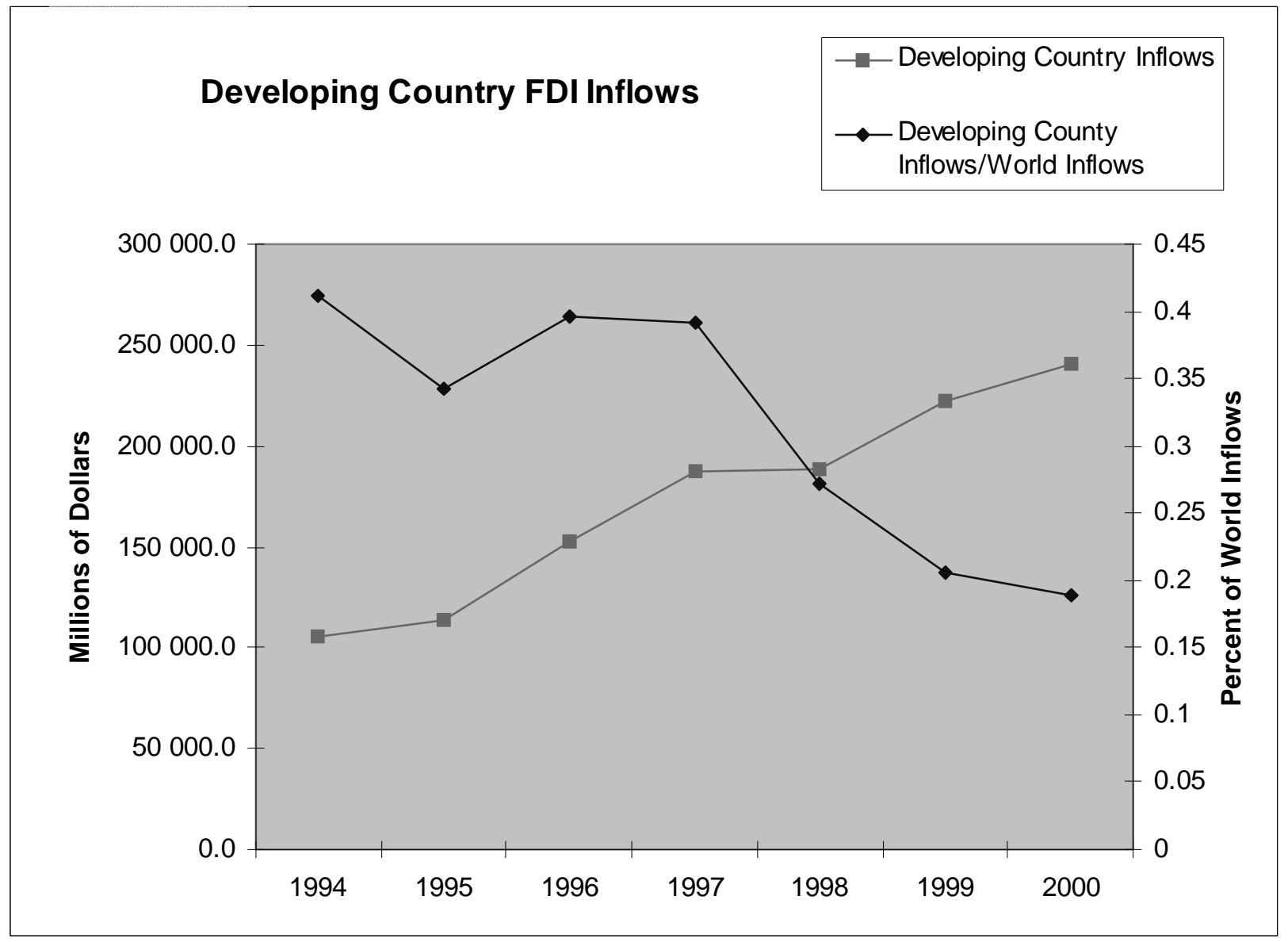

Figure 1b

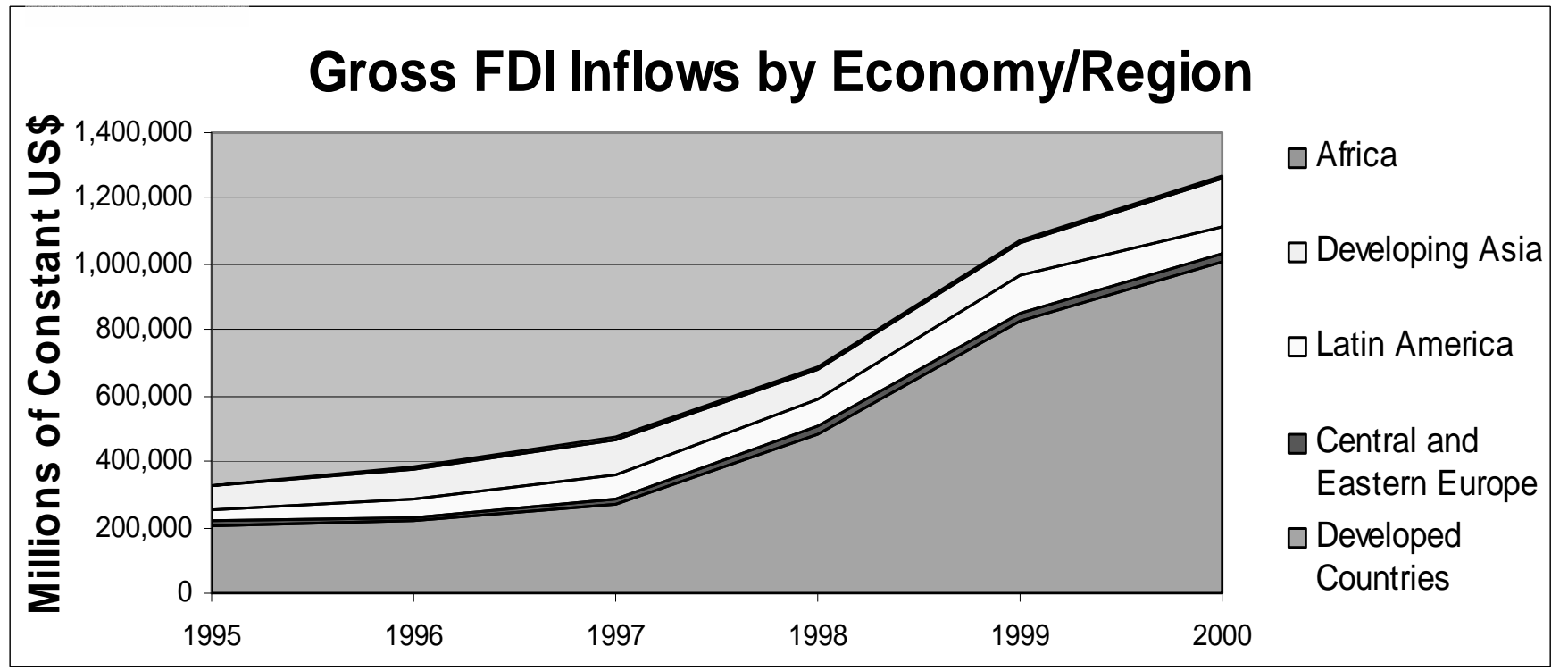


Figure 2

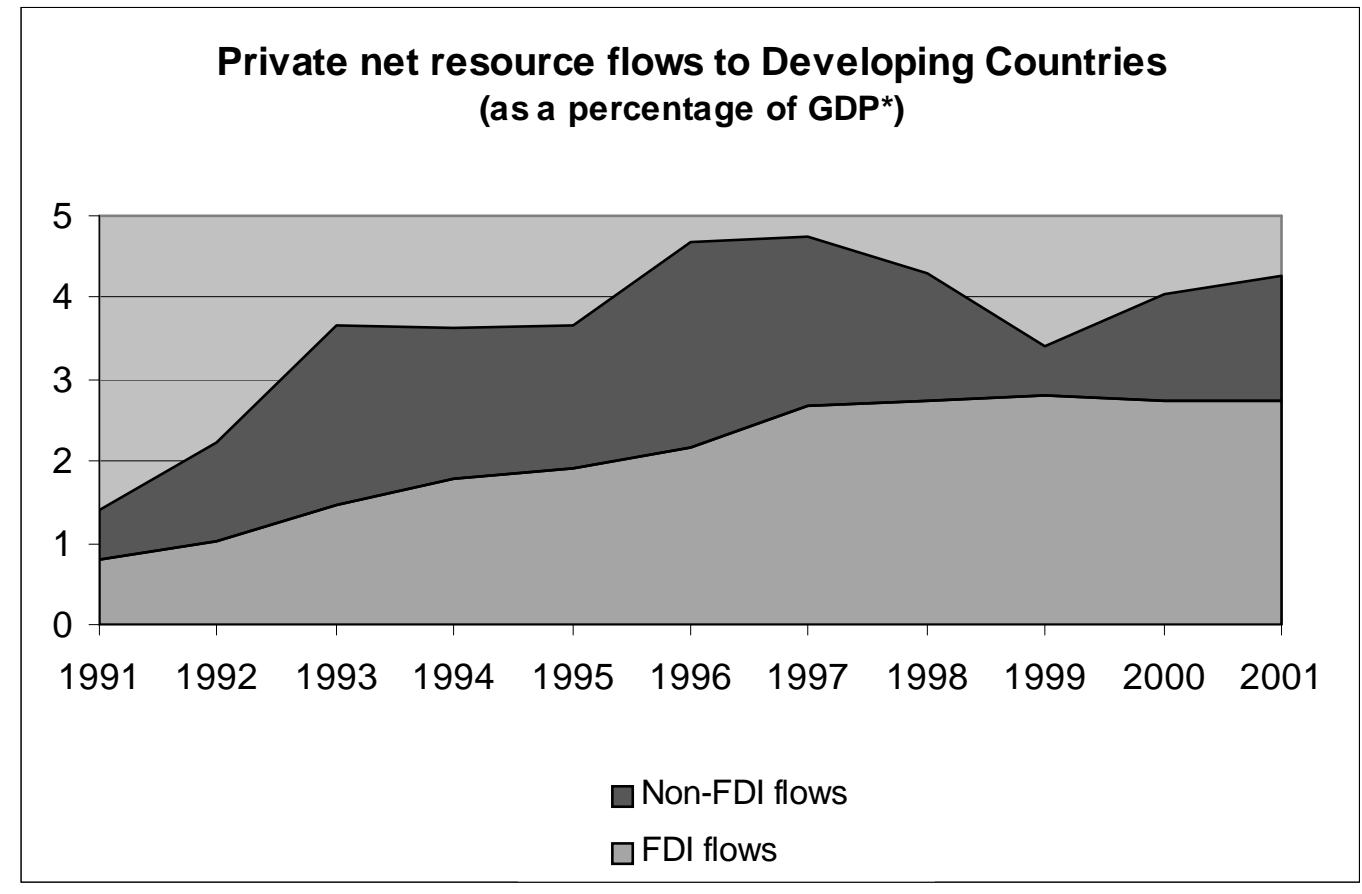

Source: IMF International Financial Statistics.

Non FDI Flows include portfolio flows and commercial bank loans

*Percentage measured relative to GDP of all developing countries as a group (developing countries listed in footnote 7). 
Figure 3
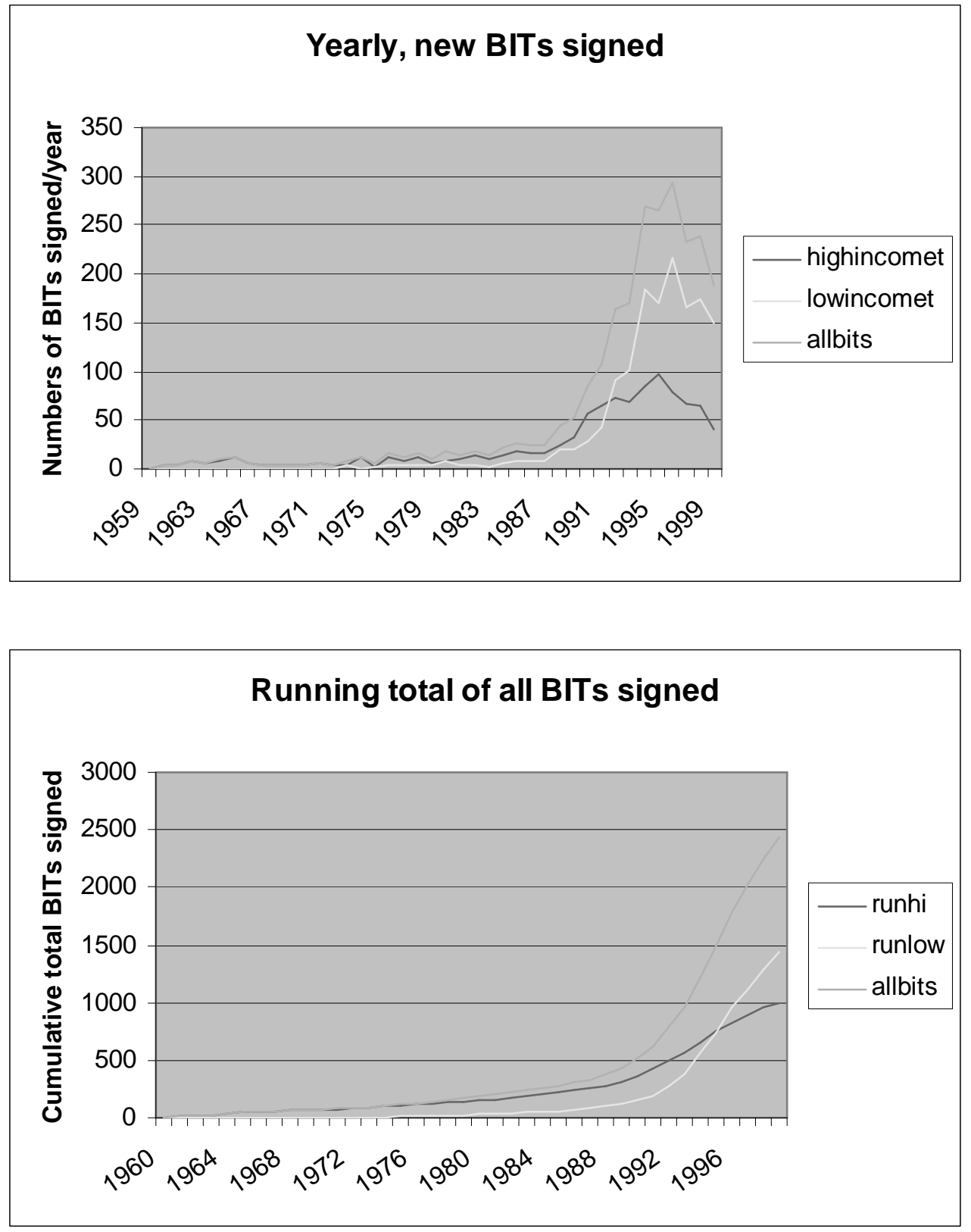
Figure 4

\section{Number of New BITs Concluded by Developing Countries, by decade}

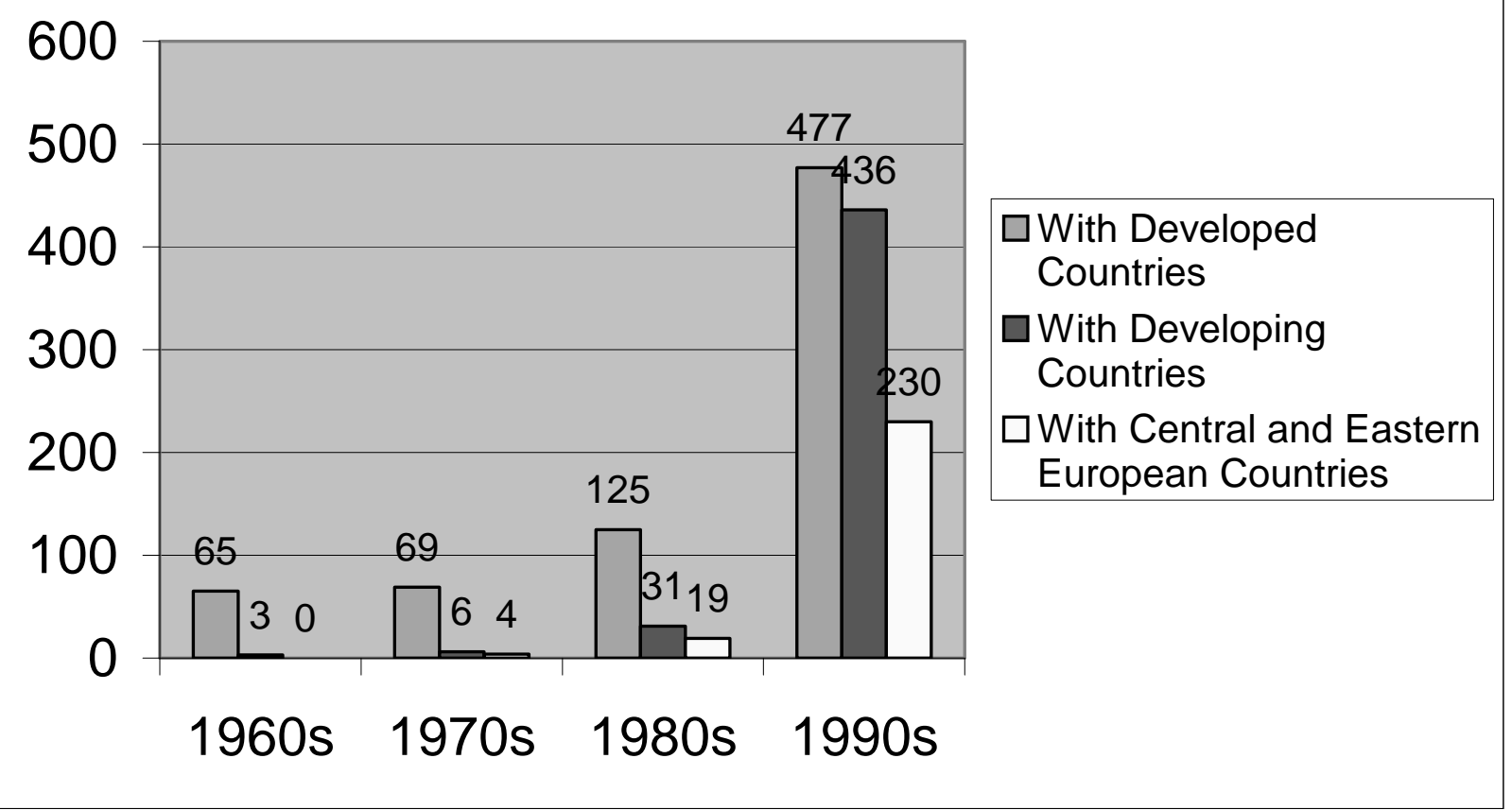

Figure 5

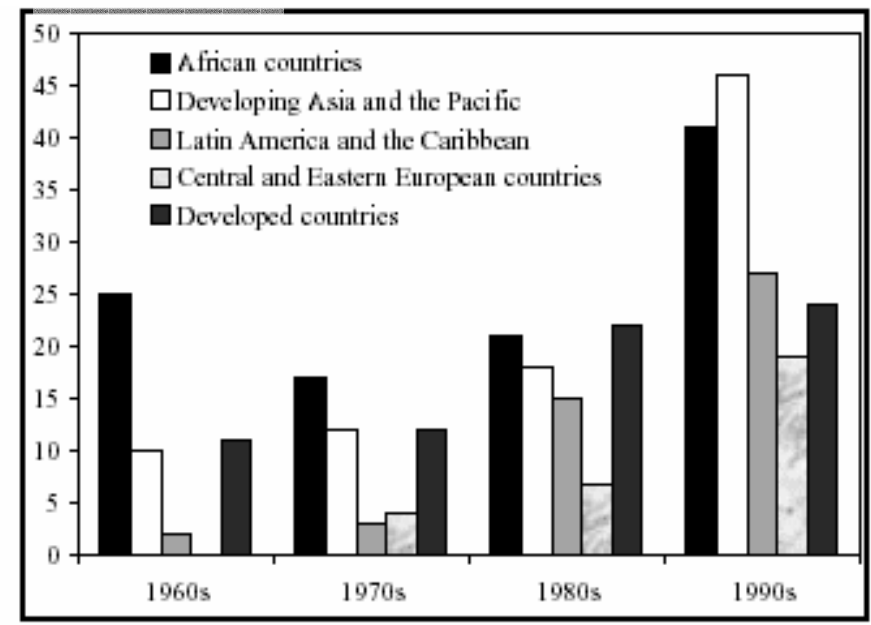

Source: UNCTAD database on BITs. 


\section{Appendix A. World Bank Income Classifications:}

The World Bank income classifications are divided according to $2000 \mathrm{GNI}$ per capita, calculated using the World Bank Atlas method. The groups are: low income, $\$ 755$ or less; lower middle income, $\$ 756$ $\$ 2,995$; upper middle income, $\$ 2,996$ - $\$ 9,265$; and high income, $\$ 9,266$ or more (see http://www.worldbank.org/data/databytopic/class.htm for more information).

\section{Low-income economies (63)}

\begin{tabular}{lll}
\hline Afghanistan & Ghana & Nicaragua \\
Angola & Guinea & Niger \\
Armenia & Guinea-Bissau & Nigeria \\
Azerbaijan & Haiti & Pakistan \\
Bangladesh & India & Rwanda \\
Benin & Indonesia & Sao Tome and Principe \\
Bhutan & Kenya & Senegal \\
Burkina Faso & Korea, Dem Rep. & Sierra Leone \\
Burundi & Kyrgyz Republic & Solomon Islands \\
Cambodia & Lao PDR & Somalia \\
Cameroon & Lesotho & Sudan \\
Central African Republic & Liberia & Tajikistan \\
Chad & Madagascar & Tanzania \\
Comoros & Malawi & Togo \\
Congo, Dem. Rep & Mali & Uganda \\
Congo, Rep. & Mauritania & Ukraine \\
Cote d'Ivoire & Moldova & Uzbekistan \\
Eritrea & Mongolia & Vietnam \\
Ethiopia & Mozambique & Yemen, Rep. \\
Gambia, The & Myanmar & Zambia \\
Georgia & Nepal & Zimbabwe
\end{tabular}

\section{Lower-middle-income economies (54)}

\begin{tabular}{lll}
\hline Albania & Guatemala & Paraguay \\
Algeria & Guyana & Peru \\
Belarus & Honduras & Philippines \\
Belize & Iran, Islamic Rep. & Romania \\
Bolivia & Iraq & Russian Federation \\
Bosnia and Herzegovina & Jamaica & Samoa \\
Bulgaria & Jordan & Sri Lanka \\
Cape Verde & Kazakhstan & St. Vincent and the Grenadines \\
China & Kiribati & Suriname \\
Colombia & Latvia & Swaziland \\
Cuba & Lithuania & Syrian Arab Republic \\
Djibouti & Macedonia, FYR & Thailand \\
Dominican Republic & Maldives & Tonga
\end{tabular}


Ecuador

Egypt, Arab Rep.

El Salvador

Equatorial Guinea

Fiji
Marshall Islands

Micronesia, Fed. Sts.

Morocco

Namibia

Papua New Guinea
Tunisia

Turkmenistan

Vanuatu

West Bank and Gaza

Yugoslavia, Fed. Rep.

\section{Upper-middle-income economies (38)}

\begin{tabular}{lll}
\hline American Samoa & Grenada & Poland \\
Antigua and Barbuda & Hungary & Puerto Rico \\
Argentina & Isle of Man & Saudi Arabia \\
Bahrain & Korea, Rep. & Seychelles \\
Botswana & Lebanon & Slovak Republic \\
Brazil & Libya & South Africa \\
Chile & Malaysia & St. Kitts and Nevis \\
Costa Rica & Mauritius & St. Lucia \\
Croatia & Mayotte & Trinidad and Tobago \\
Czech Republic & Mexico & Turkey \\
Dominica & Oman & Uruguay \\
Estonia & Palau & Venezuela, RB \\
Gabon & Panama &
\end{tabular}

\section{High-income economies (52)}

Andorra

Aruba

Australia

Austria

Bahamas, The

Barbados

Belgium

Bermuda

Brunei

Canada

Cayman Islands

Channel Islands

Cyprus

Denmark

Faeroe Islands

Finland

France

French Polynesia
Germany

Greece

Greenland

Guam

Hong Kong, China

Iceland

Ireland

Israel

Italy

Japan

Kuwait

Liechtenstein

Luxembourg

Macao, China

Malta

Monaco

Netherlands

Netherlands Antilles

\section{New Caledonia}

New Zealand

Northern Mariana Islands

Norway

Portugal

Qatar

San Marino

Singapore

Slovenia

Spain

Sweden

Switzerland

United Arab Emirates

United Kingdom

United States

Virgin Islands (U.S.) 


\title{
Appendix B
}

Source: Office of the Chief Counsel for International Commerce, U. S. Department of Commerce

\author{
THE 1994 U.S. PROTOTYPE BILATERAL INVESTMENT TREATY \\ TREATY BETWEEN THE GOVERNMENT OF THE UNITED STATES OF AMERICA \\ AND THE GOVERNMENT OF \\ CONCERNING THE ENCOURAGEMENT AND RECIPROCAL PROTECTION OF \\ INVESTMENT
}

The Government of the United States of America and the Government of (hereinafter the "Parties");

Desiring to promote greater economic cooperation between them, with respect to investment by nationals and companies of one Party in the territory of the other Party;

Recognizing that agreement upon the treatment to be accorded such investment will stimulate the flow of private capital and the economic development of the Parties;

Agreeing that a stable framework for investment will maximize effective utilization of economic resources and improve living standards;

Recognizing that the development of economic and business ties can promote respect for internationally recognized worker rights;

Agreeing that these objectives can be achieved without relaxing health, safety and environmental measures of general application; and

Having resolved to conclude a treaty concerning the encouragement and reciprocal protection of investment;

Have agreed as follows:

\section{ARTICLE I}

For the purposes of this Treaty,

(a) "company" means any entity constituted or organized under applicable law, whether or not for profit, and whether privately or governmentally owned or controlled, and includes a corporation, trust, partnership, sole proprietorship, branch, joint venture, association, or other organization;

(b) "company of a Party" means a company constituted or organized under the laws of that Party;

(c) "national" of a Party means a natural person who is a national of that Party under its applicable law;

(d) "investment" of a national or company means every kind of investment owned or controlled directly or indirectly by that national or company, and includes investment consisting or taking the form of: 


\section{Appendix B (cont'd)}

(i) a company;

(ii) shares, stock, and other forms of equity participation, and bonds, debentures, and other forms of debt interests, in a company;

(iii) contractual rights, such as under turnkey, construction or management contracts, production or revenue-sharing contracts, concessions, or other similar contracts;

(iv) tangible property, including real property; and intangible property, including rights, such as leases, mortgages, liens and pledges;

(v) intellectual property, including:

copyrights and related rights, patents, rights in plant varieties, industrial designs, rights in semiconductor layout designs, trade secrets, including know-how and confidential business information, trade and service marks, and trade names; and

(vi) rights conferred pursuant to law, such as licenses and permits;

(e) "covered investment" means an investment of a national or company of a Party in the territory of the other Party;

(f) "state enterprise" means a company owned, or controlled through ownership interests, by a Party;

(g) "investment authorization" means an authorization granted by the foreign investment authority of a Party to a covered investment or a national or company of the other Party;

(h) "investment agreement" means a written agreement between the national authorities of a Party and a covered investment or a national or company of the other Party that (i) grants rights with respect to natural resources or other assets controlled by the national authorities and (ii) the investment, national or company relies upon in establishing or acquiring a covered investment.

(i) "ICSID Convention" means the Convention on the Settlement of Investment Disputes between States and Nationals of Other States, done at Washington, March 18, 1965;

(j) "Centre" means the International Centre for Settlement of Investment Disputes established by the ICSID Convention; and

(k) "UNCITRAL Arbitration Rules" means the arbitration rules of the United Nations Commission on International Trade Law.

\section{ARTICLE II}

1. With respect to the establishment, acquisition, expansion, management, conduct, operation and sale or other disposition of covered investments, each Party shall accord treatment no less favorable than that it accords, in like situations, to investments in its territory of its own nationals or companies (hereinafter "national treatment") or to investments in its territory of nationals or companies of a third country (hereinafter "most favored nation treatment"), whichever is most 


\section{Appendix B (cont'd)}

favorable (hereinafter "national and most favored nation treatment"). Each Party shall ensure that its state enterprises, in the provision of their goods or services, accord national and most favored nation treatment to covered investments.

2. (a) A Party may adopt or maintain exceptions to the obligations of paragraph 1 in the sectors or with respect to the matters specified in the Annex to this Treaty. In adopting such an exception, a Party may not require the divestment, in whole or in part, of covered investments existing at the time the exception becomes effective.

(b) The obligations of paragraph 1 do not apply to procedures provided in multilateral agreements concluded under the auspices of the World Intellectual Property Organization relating to the acquisition or maintenance of intellectual property rights.

3. (a) Each Party shall at all times accord to covered investments fair and equitable treatment and full protection and security, and shall in no case accord treatment less favorable than that required by international law.

(b) Neither Party shall in any way impair by unreasonable and discriminatory measures the management, conduct, operation, and sale or other disposition of covered investments.

4. Each Party shall provide effective means of asserting claims and enforcing rights with respect to covered investments.

5. Each Party shall ensure that its laws, regulations, administrative practices and procedures of general application, and adjudicatory decisions, that pertain to or affect covered investments are promptly published or otherwise made publicly available.

\section{ARTICLE III}

1. Neither Party shall expropriate or nationalize a covered investment either directly or indirectly through measures tantamount to expropriation or nationalization ("expropriation") except for a public purpose; in a non-discriminatory manner; upon payment of prompt, adequate and effective compensation; and in accordance with due process of law and the general principles of treatment provided for in Article II(3).

2. Compensation shall be paid without delay; be equivalent to the fair market value of the expropriated investment immediately before the expropriatory action was taken ("the date of expropriation"); and be fully realizable and freely transferable. The fair market value shall not reflect any change in value occurring because the expropriatory action had become known before the date of expropriation.

3. If the fair market value is denominated in a freely usable currency, the compensation paid shall be no less than the fair market value on the date of expropriation, plus interest at a commercially reasonable rate for that currency, accrued from the date of expropriation until the date of payment. 


\section{Appendix B (cont'd)}

4. If the fair market value is denominated in a currency that is not freely usable, the compensation paid -- converted into the currency of payment at the market rate of exchange prevailing on the date of payment -- shall be no less than:

(a) the fair market value on the date of expropriation, converted into a freely usable currency at the market rate of exchange prevailing on that date, plus

(b) interest, at a commercially reasonable rate for that freely usable currency, accrued from the date of expropriation until the date of payment.

\section{ARTICLE IV}

1. Each Party shall accord national and most favored nation treatment to covered investments as regards any measure relating to losses that investments suffer in its territory owing to war or other armed conflict, revolution, state of national emergency, insurrection, civil disturbance, or similar events.

2. Each Party shall accord restitution, or pay compensation in accordance with paragraphs 2 through 4 of Article III, in the event that covered investments suffer losses in its territory, owing to war or other armed conflict, revolution, state of national emergency, insurrection, civil disturbance, or similar events, that result from:

(a) requisitioning of all or part of such investments by the Party's forces or authorities, or

(b) destruction of all or part of such investments by the Party's forces or authorities that was not required by the necessity of the situation.

\section{ARTICLE V}

1. Each Party shall permit all transfers relating to a covered investment to be made freely and without delay into and out of its territory. Such transfers include:

(a) contributions to capital;

(b) profits, dividends, capital gains, and proceeds from the sale of all or any part of the investment or from the partial or complete liquidation of the investment;

(c) interest, royalty payments, management fees, and technical assistance and other fees;

(d) payments made under a contract, including a loan agreement; and

(e) compensation pursuant to Articles III and IV, and payments arising out of an investment dispute.

2. Each Party shall permit transfers to be made in a freely usable currency at the market rate of exchange prevailing on the date of transfer.

3. Each Party shall permit returns in kind to be made as authorized or specified in an investment authorization, investment agreement, or other written agreement between the Party and a covered investment or a national or company of the other Party. 


\section{Appendix B (cont'd)}

4. Notwithstanding paragraphs 1 through 3, a Party may prevent a transfer through the equitable, non-discriminatory and good faith application of its laws relating to:

(a) bankruptcy, insolvency or the protection of the rights of creditors;

(b) issuing, trading or dealing in securities;

(c) criminal or penal offenses; or

(d) ensuring compliance with orders or judgments in adjudicatory proceedings.

\section{ARTICLE VI}

Neither Party shall mandate or enforce, as a condition for the establishment, acquisition, expansion, management, conduct or operation of a covered investment, any requirement (including any commitment or undertaking in connection with the receipt of a governmental permission or authorization):

(a) to achieve a particular level or percentage of local content, or to purchase, use or otherwise give a preference to products or services of domestic origin or from any domestic source;

(b) to limit imports by the investment of products or services in relation to a particular volume or value of production, exports or foreign exchange earnings;

(c) to export a particular type, level or percentage of products or services, either generally or to a specific market region;

(d) to limit sales by the investment of products or services in the Party's territory in relation to a particular volume or value of production, exports or foreign exchange earnings;

(e) to transfer technology, a production process or other proprietary knowledge to a national or company in the Party's territory, except pursuant to an order, commitment or undertaking that is enforced by a court, administrative tribunal or competition authority to remedy an alleged or adjudicated violation of competition laws; or

(f) to carry out a particular type, level or percentage of research and development in the Party's territory.

Such requirements do not include conditions for the receipt or continued receipt of an advantage.

\section{ARTICLE VII}

1. (a) Subject to its laws relating to the entry and sojourn of aliens, each Party shall permit to enter and to remain in its territory nationals of the other Party for the purpose of establishing, developing, administering or advising on the operation of an investment to which they, or a company of the other Party that employs them, have committed or are in the process of committing a substantial amount of capital or other resources. 


\section{Appendix B (cont'd)}

(b) Neither Party shall, in granting entry under paragraph 1(a), require a labor certification test or other procedures of similar effect, or apply any numerical restriction.

2. Each Party shall permit covered investments to engage top managerial personnel of their choice, regardless of nationality.

\section{ARTICLE VIII}

The Parties agree to consult promptly, on the request of either, to resolve any disputes in connection with the Treaty, or to discuss any matter relating to the interpretation or application of the Treaty or to the realization of the objectives of the Treaty.

\section{ARTICLE IX}

1. For purposes of this Treaty, an investment dispute is a dispute between a Party and a national or company of the other Party arising out of or relating to an investment authorization, an investment agreement or an alleged breach of any right conferred, created or recognized by this Treaty with respect to a covered investment.

2. A national or company that is a party to an investment dispute may submit the dispute for resolution under one of the following alternatives:

(a) to the courts or administrative tribunals of the Party that is a party to the dispute; or

(b) in accordance with any applicable, previously agreed dispute-settlement procedures; or

(c) in accordance with the terms of paragraph 3 .

3. (a) Provided that the national or company concerned has not submitted the dispute for resolution under paragraph 2(a) or (b), and that three months have elapsed from the date on which the dispute arose, the national or company concerned may submit the dispute for settlement by binding arbitration:

(i) to the Centre, if the Centre is available; or

(ii) to the Additional Facility of the Centre, if the Centre is not available; or

(iii) in accordance with the UNCITRAL Arbitration Rules; or

(iv) if agreed by both parties to the dispute, to any other arbitration institution or in accordance with any other arbitration rules.

(b) A national or company, notwithstanding that it may have submitted a dispute to binding arbitration under paragraph 3(a), may seek interim injunctive relief, not involving the payment of damages, before the judicial or administrative tribunals of the Party that is a party to the dispute, prior to the institution of the arbitral proceeding or during the proceeding, for the preservation of its rights and interests. 


\section{Appendix B (cont'd)}

4. Each Party hereby consents to the submission of any investment dispute for settlement by binding arbitration in accordance with the choice of the national or company under paragraph 3(a)(i), (ii), and (iii) or the mutual agreement of both parties to the dispute under paragraph 3(a)(iv). This consent and the submission of the dispute by a national or company under paragraph 3(a) shall satisfy the requirement of:

(a) Chapter II of the ICSID Convention (Jurisdiction of the Centre) and the Additional Facility Rules for written consent of the parties to the dispute; and

(b) Article II of the United Nations Convention on the Recognition and Enforcement of Foreign Arbitral Awards, done at New York, June 10, 1958, for an "agreement in writing".

5. Any arbitration under paragraph 3(a)(ii), (iii) or (iv) shall be held in a state that is a party to the United Nations Convention on the Recognition and Enforcement of Foreign Arbitral Awards, done at New York, June 10, 1958.

6. Any arbitral award rendered pursuant to this Article shall be final and binding on the parties to the dispute. Each Party shall carry out without delay the provisions of any such award and provide in its territory for the enforcement of such award.

7. In any proceeding involving an investment dispute, a Party shall not assert, as a defense, counterclaim, right of set-off or for any other reason, that indemnification or other compensation for all or part of the alleged damages has been received or will be received pursuant to an insurance or guarantee contract.

8. For purposes of Article 25(2)(b) of the ICSID Convention and this Article, a company of a Party that, immediately before the occurrence of the event or events giving rise to an investment dispute, was a covered investment, shall be treated as a company of the other Party.

\section{ARTICLE X}

1. Any dispute between the Parties concerning the interpretation or application of the Treaty, that is not resolved through consultations or other diplomatic channels, shall be submitted upon the request of either Party to an arbitral tribunal for binding decision in accordance with the applicable rules of international law. In the absence of an agreement by the Parties to the contrary, the UNCITRAL Arbitration Rules shall govern, except to the extent these rules are (a) modified by the Parties or (b) modified by the arbitrators unless either Party objects to the proposed modification.

2. Within two months of receipt of a request, each Party shall appoint an arbitrator. The two arbitrators shall select a third arbitrator as Chairman, who shall be a national of a third State. The UNCITRAL Arbitration Rules applicable to appointing members of three member panels shall apply mutatis mutandis to the appointment of the arbitral panel except that the appointing authority referenced in those rules shall be the Secretary General of the Centre. 


\section{Appendix B (cont'd)}

3. Unless otherwise agreed, all submissions shall be made and all hearings shall be completed within six months of the date of selection of the third arbitrator, and the arbitral panel shall render its decisions within two months of the date of the final submissions or the date of the closing of the hearings, whichever is later.

4. Expenses incurred by the Chairman and other arbitrators, and other costs of the proceedings, shall be paid for equally by the Parties. However, the arbitral panel may, at its discretion, direct that a higher proportion of the costs be paid by one of the Parties.

\section{ARTICLE XI}

This Treaty shall not derogate from any of the following that entitle covered investments to treatment more favorable than that accorded by this Treaty:

(a) laws and regulations, administrative practices or procedures, or administrative or adjudicatory decisions of a Party;

(b) international legal obligations; or

(c) obligations assumed by a Party, including those contained in an investment authorization or an investment agreement.

\section{ARTICLE XII}

Each Party reserves the right to deny to a company of the other Party the benefits of this Treaty if nationals of a third country own or control the company and

(a) the denying Party does not maintain normal economic relations with the third country; or

(b) the company has no substantial business activities in the territory of the Party under whose laws it is constituted or organized.

\section{ARTICLE XIII}

1. No provision of this Treaty shall impose obligations with respect to tax matters, except that:

(a) Articles III, IX and X will apply with respect to expropriation; and

(b) Article IX will apply with respect to an investment agreement or an investment authorization.

2. A national or company, that asserts in an investment dispute that a tax matter involves an expropriation, may submit that dispute to arbitration pursuant to Article IX(3) only if:

(a) the national or company concerned has first referred to the competent tax authorities of both Parties the issue of whether the tax matter involves an expropriation; and 


\section{Appendix B (cont'd)}

(b) the competent tax authorities have not both determined, within nine months from the time the national or company referred the issue, that the matter does not involve an expropriation.

\section{ARTICLE XIV}

1. This Treaty shall not preclude a Party from applying measures necessary for the fulfillment of its obligations with respect to the maintenance or restoration of international peace or security, or the protection of its own essential security interests.

2. This Treaty shall not preclude a Party from prescribing special formalities in connection with covered investments, such as a requirement that such investments be legally constituted under the laws and regulations of that Party, or a requirement that transfers of currency or other monetary instruments be reported, provided that such formalities shall not impair the substance of any of the rights set forth in this Treaty.

\section{ARTICLE XV}

1. (a) The obligations of this Treaty shall apply to the political subdivisions of the Parties.

(b) With respect to the treatment accorded by a State, Territory or possession of the United States of America, national treatment means treatment no less favorable than the treatment accorded thereby, in like situations, to investments of nationals of the United States of America resident in, and companies legally constituted under the laws and regulations of, other States, Territories or possessions of the United States of America.

2. A Party's obligations under this Treaty shall apply to a state enterprise in the exercise of any regulatory, administrative or other governmental authority delegated to it by that Party.

\section{ARTICLE XVI}

1. This Treaty shall enter into force thirty days after the date of exchange of instruments of ratification. It shall remain in force for a period of ten years and shall continue in force unless terminated in accordance with paragraph 2 . It shall apply to covered investments existing at the time of entry into force as well as to those established or acquired thereafter.

2. A Party may terminate this Treaty at the end of the initial ten year period or at any time thereafter by giving one year's written notice to the other Party.

3. For ten years from the date of termination, all other Articles shall continue to apply to covered investments established or acquired prior to the date of termination, except insofar as those Articles extend to the establishment or acquisition of covered investments.

4. The Annex [AND PROTOCOL (if any)] shall form an integral part of the Treaty.

IN WITNESS WHEREOF, the respective plenipotentiaries have signed this Treaty. 


\section{Appendix B (cont'd)}

DONE in duplicate at [CITY] this [NUMBER] day of [MONTH], [YEAR], in the English and languages, each text being equally authentic.

FOR THE GOVERNMENT OF THE UNITED STATES OF AMERICA:

FOR THE GOVERNMENT OF

Annex

1. The Government of the United States of America may adopt or maintain exceptions to the obligation to accord national treatment to covered investments in the sectors or with respect to the matters specified below:

atomic energy; custom house brokers; licenses for broadcast, common carrier, or aeronautical radio stations; COMSAT; subsidies or grants, including government-supported loans, guarantees and insurance; state and local measures exempt from Article 1102 of the North American Free Trade Agreement pursuant to Article 1108 thereof; landing of submarine cables.

Most favored nation treatment shall be accorded in the sectors and matters indicated above.

2. The Government of the United States of America may adopt or maintain exceptions to the obligation to accord national and most favored nation treatment to covered investments in the sectors or with respect to the matters specified below:

fisheries; air and maritime transport, and related activities; banking* insurance* securities* and other financial services*.

*Note: If the treaty partner undertakes acceptable commitments with respect to all or certain financial services, the Government of the United States of America will consider limiting these exceptions accordingly, so that, for example, particular obligations as to treatment would apply on no less favorable terms than in the North American Free Trade Agreement.

3. The Government of may adopt or maintain exceptions...

4. Notwithstanding paragraph 3, each Party agrees to accord national treatment to covered investments in the following sectors: leasing of minerals or pipeline rights-of-way on Government lands. 


\section{Appendix C: ICRG Political Risk Rating}

"The aim of the political risk rating is to provide a means of assessing the political stability of the countries covered by ICRG on a comparable basis. This is done by assigning risk points to a pre-set group of factors, termed political risk components. The minimum number of points that can be assigned to each component is zero, while the maximum number of points depends on the fixed weight that component is given in the overall political risk assessment. In every case the lower the risk point total, the higher the risk, and the higher the risk point total the lower the risk."

"To ensure consistency, both between countries and over time, points are assigned by ICRG editors on the basis of a series of pre-set questions for each risk component."

\section{ICRG Political Risk Components}

Component

Government Stability:

Socioeconomic Conditions:

Investment Profile:

Internal Conflict:

External Conflict:

Corruption:

Military in Politics

Religious Tensions

Law and Order:

Ethnic Tensions:

Democratic Accountability

Bureaucracy Quality

Total
Definition

Maximum Points

\begin{abstract}
Ability to stay in office and to carry out its declared programs, based on measures of government unity, legislative strength and popular support
\end{abstract}

that may constrain government action: unemployment, consumer confidence, poverty

Contract viability/expropriation, profits repatriation, and payment delays

impact of political violence on governance: civil war/terrorism/political violence, civil disorder

risk to government of external actions from non-violent external pressure such as trade restrictions or withholding of aid to violent pressure, based on war, cross-border conflict, foreign pressures

Financial corruption such as bribes connected with licenses, regulation and taxes, focuses more on "actual or potential corruption in the form of excessive patronage, nepotism, job reservations, favor for favors, secret party funding, and suspiciously close ties between politics and business.

strength and impartiality of the legal system and popular observance of the law

racial, nationality of language divisions 
Appendix D: Countries included in regressions

\begin{tabular}{|c|c|c|}
\hline $\begin{array}{l}\text { FDI: Included } \\
\text { Countries }\end{array}$ & $\begin{array}{l}\text { US Bilateral FDI: } \\
\text { Included Countries }\end{array}$ & $\begin{array}{l}\text { Private Investment: } \\
\text { Included Countries }\end{array}$ \\
\hline ALGERIA & ALGERIA & ALGERIA \\
\hline ARGENTINA & ARGENTINA & ARGENTINA \\
\hline BOLIVIA & BANGLADESH & BANGLADESH \\
\hline BRAZIL & BOLIVIA & BOLIVIA \\
\hline CAMEROON & BOTSWANA & BRAZIL \\
\hline CHILE & BRAZIL & CHILE \\
\hline COLOMBIA & CAMEROON & COLOMBIA \\
\hline COSTA RICA & CHILE & COSTA RICA \\
\hline DOMINICAN REP. & CHINA & COTE D'IVOIRE \\
\hline ECUADOR & COLOMBIA & DOMINICAN REPUBLIC \\
\hline EGYPT & COSTA RICA & ECUADOR \\
\hline EL SALVADOR & DOMINICAN REPUBLIC & EGYPT \\
\hline GAMBIA & ECUADOR & EL SALVADOR \\
\hline GHANA & EGYPT & GUATEMALA \\
\hline GUATEMALA & EL SALVADOR & GUINEA-BISSAU \\
\hline GUYANA & GHANA & GUYANA \\
\hline HAITI & GUATEMALA & HAITI \\
\hline HONDURAS & GUYANA & INDIA \\
\hline INDIA & HAITI & INDONESIA \\
\hline INDONESIA & HONDURAS & IRAN \\
\hline IRAN & HUNGARY & KENYA \\
\hline JAMAICA & INDIA & MADAGASCAR \\
\hline KENYA & INDONESIA & MALAWI \\
\hline MALAWI & IRAN & MALAYSIA \\
\hline MALAYSIA & KENYA & MEXICO \\
\hline MEXICO & MALAYSIA & MOROCCO \\
\hline NICARAGUA & MALI & NICARAGUA \\
\hline NIGER & MEXICO & PAKISTAN \\
\hline PAKISTAN & NICARAGUA & PANAMA \\
\hline PANAMA & NIGER & PAPUA NEW GUINEA \\
\hline PAPUA NEW GUINEA & PAKISTAN & PARAGUAY \\
\hline PARAGUAY & PANAMA & PERU \\
\hline PERU & PAPUA NEW GUINEA & PHILIPPINES \\
\hline PHILIPPINES & PARAGUAY & SOUTH AFRICA \\
\hline SENEGAL & PERU & THAILAND \\
\hline SIERRA LEONE & PHILIPPINES & TRINIDAD \& TOBAGO \\
\hline SOUTH AFRICA & SENEGAL & TUNISIA \\
\hline SRI LANKA & SOUTH AFRICA & TURKEY \\
\hline SYRIA & SRI LANKA & URUGUAY \\
\hline THAILAND & THAILAND & VENEZUELA \\
\hline TOGO & TOGO & \\
\hline TRINIDAD \& TOBAGO & TRINIDAD \& TOBAGO & \\
\hline URUGUAY & TUNISIA & \\
\hline VENEZUELA & TURKEY & \\
\hline \multirow[t]{4}{*}{ ZIMBABWE } & URUGUAY & \\
\hline & VENEZUELA & \\
\hline & ZAMBIA & \\
\hline & ZIMBABWE & \\
\hline
\end{tabular}


Appendix D (Cont'd.)

Property Rights:

Included Countries

\begin{tabular}{|c|c|}
\hline ALGERIA & PARAGUAY \\
\hline ARGENTINA & PERU \\
\hline BAHRAIN & PHILIPPINES \\
\hline BANGLADESH & SAUDI ARABIA \\
\hline BOLIVIA & SENEGAL \\
\hline BOTSWANA & SIERRA LEONE \\
\hline BRAZIL & SOUTH AFRICA \\
\hline BURKINA FASO & SRI LANKA \\
\hline CAMEROON & SURINAME \\
\hline CHILE & SYRIA \\
\hline CHINA & THAILAND \\
\hline COLOMBIA & TOGO \\
\hline CONGO & TRINIDAD \& TOBAGO \\
\hline COSTA RICA & TUNISIA \\
\hline COTE D'IVOIRE & TURKEY \\
\hline DOMINICAN REP. & UGANDA \\
\hline ECUADOR & URUGUAY \\
\hline EGYPT & VENEZUELA \\
\hline EL SALVADOR & ZAMBIA \\
\hline ETHIOPIA & ZIMBABWE \\
\hline \multicolumn{2}{|l|}{ GABON } \\
\hline \multicolumn{2}{|l|}{ GAMBIA } \\
\hline \multicolumn{2}{|l|}{ GHANA } \\
\hline \multicolumn{2}{|l|}{ GUATEMALA } \\
\hline \multicolumn{2}{|l|}{ GUINEA-BISSAU } \\
\hline \multicolumn{2}{|l|}{ GUYANA } \\
\hline \multicolumn{2}{|l|}{ HAITI } \\
\hline \multicolumn{2}{|l|}{ HONDURAS } \\
\hline \multicolumn{2}{|l|}{ HUNGARY } \\
\hline \multicolumn{2}{|l|}{ INDIA } \\
\hline \multicolumn{2}{|l|}{ INDONESIA } \\
\hline \multicolumn{2}{|l|}{ IRAN } \\
\hline \multicolumn{2}{|l|}{ JAMAICA } \\
\hline \multicolumn{2}{|l|}{ JORDAN } \\
\hline \multicolumn{2}{|l|}{ KENYA } \\
\hline \multicolumn{2}{|l|}{ MADAGASCAR } \\
\hline \multicolumn{2}{|l|}{ MALAWI } \\
\hline \multicolumn{2}{|l|}{ MALAYSIA } \\
\hline \multicolumn{2}{|l|}{ MALI } \\
\hline \multicolumn{2}{|l|}{ MEXICO } \\
\hline \multicolumn{2}{|l|}{ MOROCCO } \\
\hline \multicolumn{2}{|l|}{ NICARAGUA } \\
\hline \multicolumn{2}{|l|}{ NIGER } \\
\hline \multicolumn{2}{|l|}{ NIGERIA } \\
\hline OMAN & \\
\hline PAKISTAN & \\
\hline PANAMA & \\
\hline PAPUA NEW GUII & \\
\hline
\end{tabular}




\section{Appendix E}

\section{Description of variables}

Variable Name

\section{Dependent Variables}

Foreign Direct Investment

Private Domestic Investment

Property Rights

\section{Description and Source}

Measures the total US dollar amounts of foreign direct investment flowing into a country each year, divided by the total amount of World FDI inflows that year.

Source: UNCTAD database on FDI

The difference between total gross domestic investment(from national accounts) and consolidated public investment.

Source: World Development Indicators

Measured as the sum of three indicators from the ICRG's political risk scale: Investment profile: the sum of the investment profile (measure of the risk of expropriation and contract viability), law and order and corruption. Scale is out of a total possible of 24.

source: International Country Risk Guide

\section{Independent Variables}

Bilateral Investment Treaties, with Equal to the number of treaties signed with high-income countries for a developed countries particular year.

Source: UNCTAD database on bilateral investment treaties.

Bilateral Investment Treaties, with Equal to the number of treaties signed with developing countries for a developing countries particular year.

Source: UNCTAD database on bilateral investment treaties.

Political Risk
Assessment of the "political stability of the countries covered by ICRG on a comparable basis", by assigning risk points to a pre- set group of risk components. The minimum number of points assigned to each component is zero, while the maximum number of points is a function of the components weight in the overall political risk assessment. The risk components (and maximum points) are: Government stability (e. g., popular support) (12), Socioeconomic conditions (e. g., poverty) (12), Investment profile (e. g., expropriation) (12), Internal conflict (e. g., terrorism or civil war) (12), External conflict (e. g., war) (12), Corruption (6), Military in politics (6), Religion in politics (6), Law and order (6), Ethnic tensions (6), Democratic accountability (6) and Bureaucracy Quality (4). Scale from zero to 100; low scores indicate high political risk.

source: International Country Risk Guide 


\section{Appendix E(Cont'd)}

\begin{tabular}{|c|c|}
\hline Variable Name & Description and Source \\
\hline \multirow[t]{2}{*}{ Log GNP Per Capita } & $\begin{array}{l}\text { Logarithm of GNP per capita expressed in current U.S. dollars for the } \\
\text { period 1970-1995. }\end{array}$ \\
\hline & Source: WDI. \\
\hline \multirow[t]{2}{*}{ Growth } & $\begin{array}{l}\text { Growth rate of per capita GDP, measured as the percent change per } \\
\text { year in GDP }\end{array}$ \\
\hline & Source: World Development Indicators. \\
\hline \multirow[t]{2}{*}{ Latitude } & $\begin{array}{l}\text { The absolute value of the latitude of the country, scaled to take values } \\
\text { between } 0 \text { and } 1 \text {. }\end{array}$ \\
\hline & Source: CIA 1996. \\
\hline \multirow[t]{2}{*}{ Continent } & $\begin{array}{l}\text { Dummy variables by continent for Africa, Asia, Latin America and } \\
\text { Eastern Europe. Variables equal } 1 \text { if country is located on that } \\
\text { continent. }\end{array}$ \\
\hline & Source: CIA 1996. \\
\hline \multirow[t]{2}{*}{ Natural Resources } & $\begin{array}{l}\text { Measures total US dollar amounts of natural fuels and ores exported } \\
\text { from individual countries. }\end{array}$ \\
\hline & Source: IMF's International Financial Statistics Database. \\
\hline Liquid Liabilities & $\begin{array}{l}\text { Defined by the World Development Indicators as "the sum of currency } \\
\text { and deposits in the central bank, plus transferable deposits and } \\
\text { electronic currency, plus time and savings deposits, foreign currency } \\
\text { transferable deposits, certificates of deposit, and securities repurchase } \\
\text { agreements, plus travelers checks, foreign currency time deposits, } \\
\text { commercial paper, and shares of mutual funds or market funds held by } \\
\text { residents." Measured as a percent of GDP }\end{array}$ \\
\hline
\end{tabular}

Source:Levine-Loayza-Beck Dataset, World Bank

Black Market Premium

Inflation

Population

Socio-economic indicator
Ratio of black market exchange rate and official exchange rate minus one.

Source:Levine-Loayza-Beck Dataset, World Bank

Inflation rates are calculated using average annual CPI data.

Source: International Financial Statistics

Total population in millions in a country each year.

Source: World Development Indicators.

Rating of socio-economic conditions in a country such as poverty levels and unemployment as part of the political risk measure.

Source: ICRG 


\section{Appendix F}

Summary Statistics: FDI Regressions

\begin{tabular}{lrrrrr}
\multicolumn{1}{r}{ Variable } & Obs & Mean & \multicolumn{1}{c}{ Std. Dev. } & \multicolumn{1}{c}{ Min } & \multicolumn{1}{c}{ Max } \\
\hline FDI & 128 & 0.27 & 0.58 & -0.16 & 3.61 \\
Hi Income BITs & 128 & 1.95 & 2.90 & 0 & 13 \\
Low Income BITs & 128 & 0.58 & 1.35 & 0 & 8 \\
Cumulative Total BITs & 128 & 2.5 & 4 & 0 & 21 \\
Ln GDP per capita & 128 & 7.03 & 0.92 & 4.98 & 8.96 \\
Political Risk & 128 & 51.29 & 10.64 & 26 & 77 \\
GDP growth & 128 & 4.38 & 4.01 & 0 & 22.17 \\
Black Market Premium & 128 & 1.90 & 10.11 & -0.04 & 109.91 \\
Natural Resources & 128 & 24.83 & 28.52 & 0 & 98.61 \\
Latitude Abstract & 128 & 0.18 & 0.10 & 0.01 & 0.39 \\
Ln Population & 128 & 16.4 & 1.42 & 13.5 & 20.6 \\
\hline
\end{tabular}

\begin{tabular}{lrrrrr}
\hline \multicolumn{7}{c}{ Summary Statistics: } & Private Investment Regressions & \\
\multicolumn{1}{c}{ Variable } & Obs & Mean & Std. Dev. & \multicolumn{1}{c}{ Min } & Max \\
\hline Private Investment & 142 & 13.50 & 4.78 & 3.06 & 32.50 \\
Hi Income BITs & 142 & 3.38 & 4.11 & 0 & 17 \\
Low Income BITs & 142 & 2.33 & 5.07 & 0 & 28 \\
Cumulative Total BITs & 142 & 5.71 & 8.64 & 0 & 43 \\
Ln GDP per capita & 142 & 7.09 & 0.95 & 4.90 & 8.86 \\
Political Risk & 142 & 54.69 & 11.30 & 26 & 77 \\
GDP growth & 142 & 4.07 & 2.55 & -2.37 & 10.28 \\
Liquid Liabilities & 142 & 34.53 & 16.57 & 0.57 & 90.01 \\
Natural Resources & 142 & 21.04 & 26.14 & 0 & 97.12 \\
Latitude Abstract & 142 & 0.20 & 0.12 & 0.01 & 0.43 \\
\hline
\end{tabular}

\section{Summary Statistics: Property Rights Regression}

\begin{tabular}{lrrrrr}
\multicolumn{1}{r}{ Variable } & Obs & \multicolumn{1}{c}{ Mean } & Std. Dev. & \multicolumn{1}{c}{ Min } & \multicolumn{1}{c}{ Max } \\
\hline Property Rights & 255 & 11.31 & 2.76 & 3 & 18.60 \\
Cumulative Total BITs & 255 & 9.16 & 13.96 & 0 & 94 \\
Hi Income BITs & 255 & 4.61 & 4.95 & 0 & 24 \\
Low Income BITs & 255 & 4.55 & 9.71 & 0 & 70 \\
GDP growth & 255 & 4.43 & 4.22 & 0 & 25.01 \\
Ln GDP per capita & 255 & 6.98 & 1.07 & 4.51 & 9.36 \\
Natural Resources & 255 & 22.69 & 27.53 & 0 & 98.61 \\
Socio-economic Indicator & 255 & 5.34 & 1.33 & 1.40 & 9 \\
\hline
\end{tabular}




\section{Appendix F (Cont'd)}

Correlations: Property Rights

\begin{tabular}{|c|c|c|c|c|c|c|c|c|c|c|}
\hline & $\begin{array}{l}\text { Property } \\
\text { Rights }\end{array}$ & Total BITs & $\begin{array}{l}\text { Hi income } \\
\text { BITs }\end{array}$ & $\begin{array}{l}\text { Low Income } \\
\text { BITs }\end{array}$ & $\begin{array}{l}\text { GDP } \\
\text { Growth }\end{array}$ & $\begin{array}{l}\text { Log GDP } \\
\text { per capita }\end{array}$ & Time & $\begin{array}{l}\text { Natural } \\
\text { Resources }\end{array}$ & Inflation & $\begin{array}{l}\text { Socio-econ. } \\
\text { Indicator }\end{array}$ \\
\hline Property Rights & 1.00 & & & & & & & & & \\
\hline Total BITs & 0.25 & 1.00 & & & & & & & & \\
\hline $\mathrm{Hi}$ income BITs & 0.22 & 0.93 & 1.00 & & & & & & & \\
\hline Low Income BITs & 0.25 & 0.97 & 0.81 & 1.00 & & & & & & \\
\hline GDP Growth & 0.00 & 0.05 & 0.05 & 0.04 & 1.00 & & & & & \\
\hline Log GDP per capita & 0.40 & 0.16 & 0.12 & 0.16 & 0.08 & 1.00 & & & & \\
\hline Time & 0.35 & 0.30 & 0.31 & 0.28 & 0.18 & 0.15 & 1.00 & & & \\
\hline Natural Resources & 0.02 & 0.00 & 0.00 & 0.00 & 0.09 & 0.27 & -0.03 & 1.00 & & \\
\hline Inflation & -0.08 & -0.01 & -0.01 & -0.01 & -0.10 & 0.02 & -0.06 & 0.03 & 1.00 & \\
\hline Socio-econ. Indicator & 0.44 & 0.17 & 0.18 & 0.15 & 0.06 & 0.33 & -0.30 & 0.11 & -0.09 & 1.00 \\
\hline
\end{tabular}




\section{Appendix F (Cont'd)}

\begin{tabular}{|c|c|c|c|c|c|c|c|c|c|c|c|c|c|c|c|}
\hline & \multicolumn{15}{|c|}{ Correlations between Variables: Private Investment } \\
\hline & $\begin{array}{l}\text { Private } \\
\text { Investment }\end{array}$ & $\begin{array}{l}\mathrm{Hi} \\
\text { income } \\
\text { BITs }\end{array}$ & $\begin{array}{l}\text { Low } \\
\text { Income } \\
\text { BITs } \\
\end{array}$ & $\begin{array}{l}\text { Total } \\
\text { BITs }\end{array}$ & $\begin{array}{l}\text { Log GDP } \\
\text { per capita }\end{array}$ & $\begin{array}{ll} & \\
\text { Political } & \\
\text { Risk } & \mathrm{F} \\
\end{array}$ & $\begin{array}{l}\text { GDP } \\
\text { Growth } \\
\text { Rate } \\
\end{array}$ & $\begin{array}{l}\text { Liquid } \\
\text { Liabilities }\end{array}$ & Time & Inflation & $\begin{array}{l}\text { Taxes } \\
\text { on } \\
\text { goods }\end{array}$ & $\begin{array}{l}\text { Natural } \\
\text { Resources }\end{array}$ & $\begin{array}{l}\text { Latitude } \\
\text { Abstract } \\
\end{array}$ & $\begin{array}{l}\text { Eastern } \\
\text { Europe, } \\
\text { FSU }\end{array}$ & $\begin{array}{l}\text { Latin } \\
\text { America/Car Africa }\end{array}$ \\
\hline $\begin{array}{l}\text { Private } \\
\text { Investment }\end{array}$ & 1 & I & & & & & & & & & & & & & \\
\hline $\mathrm{Hi}$ income BITs & 0.13 & 1.00 & & & & & & & & & & & & & \\
\hline Low Income BITs & 0.06 & 0.81 & 1.00 & & & & & & & & & & & & \\
\hline Total BITs & 0.10 & 0.93 & 0.97 & 1.00 & & & & & & & & & & & \\
\hline $\begin{array}{l}\text { Log GDP per } \\
\text { capita }\end{array}$ & 0.37 & 0.05 & 0.08 & 0.07 & 1.00 & & & & & & & & & & \\
\hline Political Risk & 0.24 & 0.43 & 0.35 & 0.40 & 0.40 & 1.00 & & & & & & & & & \\
\hline GDP Growth Rate & 0.21 & 0.03 & 0.04 & 0.04 & 0.03 & 0.05 & 1.00 & & & & & & & & \\
\hline $\begin{array}{l}\text { Liquid } \\
\text { Liabilities }\end{array}$ & 0.24 & 0.04 & 0.10 & 0.08 & 0.37 & 0.10 & -0.02 & 1.00 & & & & & & & \\
\hline Time & 0.18 & 0.52 & 0.40 & 0.47 & 0.00 & 0.43 & 0.05 & -0.01 & 1.00 & & & & & & \\
\hline Inflation & -0.04 & -0.05 & -0.03 & -0.04 & -0.01 & -0.08 & -0.19 & -0.05 & -0.06 & 1.00 & & & & & \\
\hline Taxes on goods & 0.09 & 0.08 & 0.06 & 0.07 & -0.01 & 0.04 & -0.16 & -0.05 & 0.00 & 0.09 & 1.00 & & & & \\
\hline $\begin{array}{l}\text { Natural } \\
\text { Resources }\end{array}$ & -0.04 & 0.00 & -0.01 & -0.01 & 0.25 & 0.03 & -0.01 & 0.05 & -0.03 & 0.03 & -0.12 & 1.00 & & & \\
\hline $\begin{array}{l}\text { Latitude } \\
\text { Abstract }\end{array}$ & -0.12 & 0.10 & 0.19 & 0.16 & 0.24 & 0.11 & 0.01 & 0.28 & 0.00 & -0.02 & 0.10 & 0.05 & 1.00 & & \\
\hline $\begin{array}{l}\text { Eastern Europe, } \\
\text { FSU }\end{array}$ & -0.01 & 0.13 & 0.12 & 0.13 & 0.25 & 0.27 & -0.25 & 0.03 & 0.00 & 0.14 & 0.23 & -0.05 & 0.31 & 1.00 & \\
\hline $\begin{array}{l}\text { Latin } \\
\text { America/Car }\end{array}$ & 0.03 & -0.07 & -0.06 & -0.07 & 0.36 & 0.07 & -0.01 & 0.02 & 0.00 & 0.03 & 0.16 & 0.04 & -0.11 & -0.23 & 1.00 \\
\hline Africa & -0.24 & -0.08 & -0.16 & -0.14 & -0.50 & -0.21 & 0.01 & -0.36 & 0.00 & -0.02 & -0.19 & -0.15 & -0.36 & -0.30 & -0.37 \\
\hline
\end{tabular}




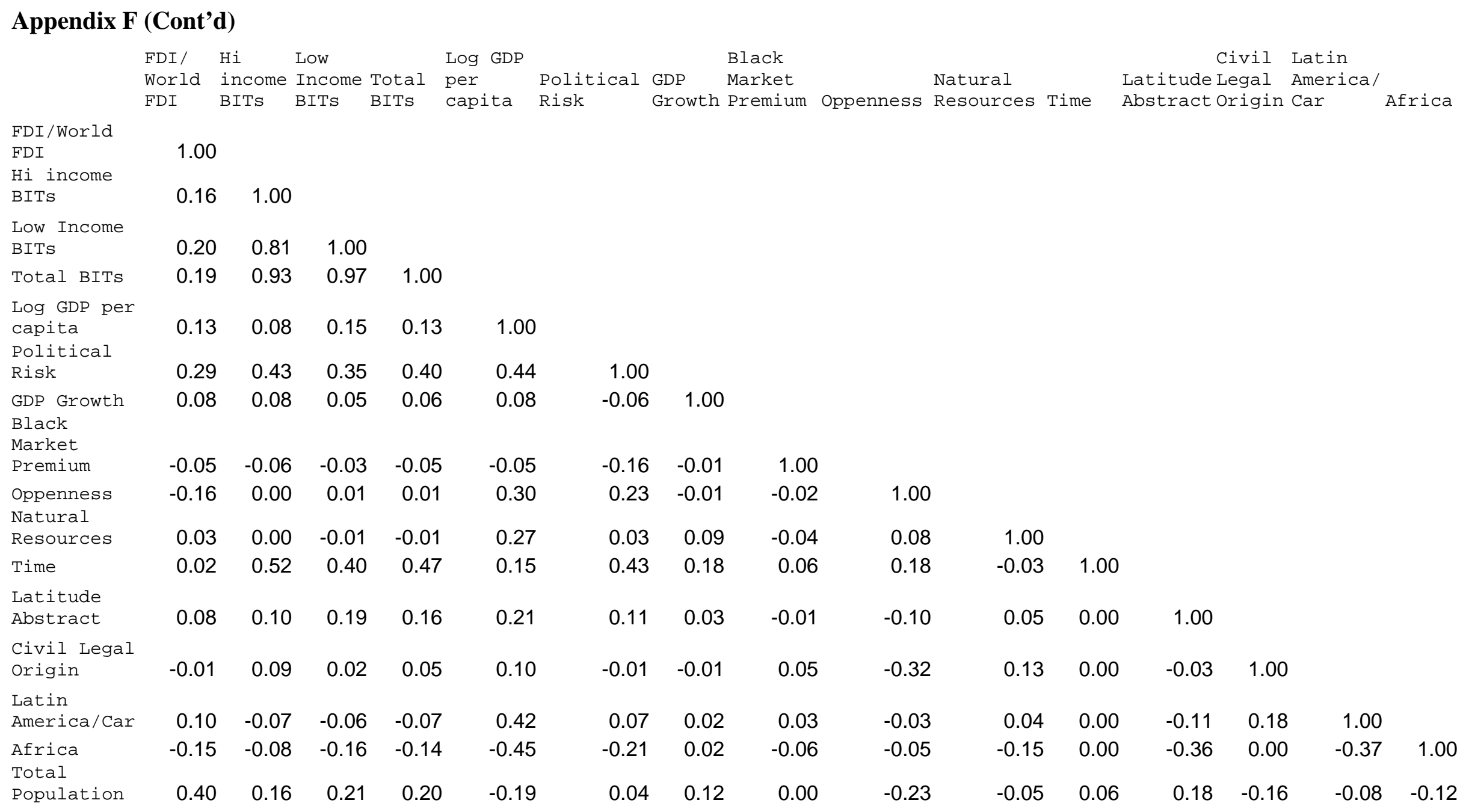




\section{Appendix G}

\begin{tabular}{|c|c|c|c|}
\hline Country & Date of Signature & $\begin{array}{c}\text { Rank of Country in FDI } \\
\text { inflows out of all developing } \\
\text { countries at year of signing } \\
\text { the treaty }\end{array}$ & $\begin{array}{l}\text { Number of countries } \\
\text { ahead in ranking } \\
\text { without treaty in place }\end{array}$ \\
\hline Panama & $27-$ Oct- 82 & 6 & 5 \\
\hline Senegal & 6-Dec-83 & 24 & 22 \\
\hline Haiti & 13-Dec-83 & 64 & 62 \\
\hline \begin{tabular}{|l} 
Democratic \\
Republic of Congo
\end{tabular} & 3-Aug-84 & 77 & 74 \\
\hline Morocco & 22-Jul-85 & 36 & 33 \\
\hline Turkey & 3-Dec-85 & 19 & 18 \\
\hline Cameroon & 26-Feb-86 & 99 & 91 \\
\hline Egypt & 11-Mar-86 & 80 & 72 \\
\hline Bangladesh & 12-Mar-86 & 50 & 45 \\
\hline Grenada & 2-May-86 & 39 & 35 \\
\hline Poland & 21-Mar-90 & 47 & 40 \\
\hline Tunisia & 15-May-90 & 35 & 30 \\
\hline Sri Lanka & 20-Sep-91 & 49 & 38 \\
\hline Czech Republic & 22-Oct-91 & 112 & 97 \\
\hline Slovakia & 22-Oct-91 & 135 & 119 \\
\hline Argentina & 14-Nov-91 & 8 & 6 \\
\hline Kazakhstan & 19-May-92 & 122 & 102 \\
\hline Romania & 28-May-92 & 36 & 28 \\
\hline Russia & 17-Jun-92 & 33 & 27 \\
\hline Armenia & 23-Sep-92 & 97 & 81 \\
\hline Bulgaria & 23-Sep-92 & 53 & 42 \\
\hline Ecuador & 27-Aug-93 & 16 & 12 \\
\hline Belarus & 15-Jan-94 & 73 & 53 \\
\hline Jamaica & 4-Feb-94 & 21 & 16 \\
\hline Ukraine & 4-Mar-94 & 137 & 109 \\
\hline Georgia & 7-Mar-94 & 79 & 58 \\
\hline Estonia & 19-Apr-94 & 113 & 87 \\
\hline Trinidad \& Tobago & 26-Sep-94 & 28 & 20 \\
\hline Mongolia & 6-Oct-94 & 126 & 98 \\
\hline Uzbekistan & 16-Dec-94 & 140 & 111 \\
\hline Albania & 11-Jan-95 & 74 & 55 \\
\hline Latvia & 13-Jan-95 & 118 & 88 \\
\hline Honduras & 1-Jul-95 & 84 & 61 \\
\hline Nicaragua & 1-Jul-95 & 126 & 95 \\
\hline Croatia & 13-Jul-96 & 112 & 82 \\
\hline Jordan & 2-Jul-97 & 120 & 86 \\
\hline Azerbaijan & 1-Aug-97 & 13 & 11 \\
\hline Lithuania & 14-Jan-98 & 80 & 53 \\
\hline Bolivia & 17-Apr-98 & 32 & 20 \\
\hline Mozambique & 1-Dec-98 & 58 & 36 \\
\hline El Salvador & 10-Mar-99 & 23 & 13 \\
\hline
\end{tabular}




\section{References:}

Abbott, Frederick M. 2000. "NAFTA and the Legalization of World Politics: A Case Study." International Organization, 54: 519-47

Alchian, Armen and Harold Demsetz. 1972. "Production, Information Costs, and Economic Organization." , 62:777-95

Allio, Lorene, Mariusz Dobek, Nikolai Mikhailov and David Weimer. 1997. "Post-Communist as a Test of Theories of Institutional Change." In David Weimer, ed., The Political Economy of Property Rights: Institutional change and credibility in the reform of centrally planned economies. Cambridge University Press, New York.

Anderson, James, Daniel Kaufmann and Francesca Recanatini. 2003. "Service Delivery, Poverty and Corruption Common Threads from Diagnostic Surveys." Background Paper for the 2004 World Development Report: Making Services Work for Poor People. The World Bank, Washington, DC.

Anderson, James. 1998. "Corruption in Latvia: Survey Evidence." World Bank Working Paper. The World Bank, Washington, DC.

2000. "Corruption in Slovakia: Results of Diagnostic Surveys." World Bank Working Paper. The World Bank, Washington, DC.

Appel, Hillary. 2000. "The Ideological Determinants of Liberal Economic Reform: the Case of Privatization." World Politics, 52:520-49.

Barzel, Yoram. 1989. Economics of Property Rights. Cambridge University Press, New York.

Cambridge. 1997. Economic Analysis of Property Rights. Cambridge University Press.

2002. Theory of the State : Economic Rights, Legal Rights, and the Scope of the State. Cambridge University Press, Cambridge.

Bates, Robert. 1995. "Social Dilemmas and Rational Individuals: An assessment of the new institutionalism." In John Harriss, Janet Hunet and Colin Lewis, eds. The New Institutional Economics and Third World Development. Routledge, London.

Beck, Nathaniel and Jonathan Katz. 1995. "What to do (and not to do) with time-series crosssection data." American Political Science Review, 89: 634-48. 
Beck, Thorsten, George Clarke, Alberto Groff, Philip Keefer, and Patrick Walsh. 2001. "New tools in comparative political economy: The Database of Political Institutions." World Bank Economic Review, 15:1:165-176.

Bénassy-Quéré, Agnès, Lionel Fontagné, and Amina Lahrèche-Révil. 1999. "Exchange rate Strategies in the Competition for Attracting FDI." Centre D'Etudes Prosectives et d'Informations Internationales(CEPII) Document de Travail Number 99-16.

Besley, Timothy. 1995. "Property rights and investment incentives: Theory and evidence from Ghana." Journal of Political Economy, 103:903-37.

Billington, Nicholas 1999. "The Location of Foreign Direct Investment: An Empirical Analysis." Applied Economics, 31:65-76.

Blomstrom, Magnus, Robert Lipsey, and Mario Zejan. 1996. "Is Fixed Investment the Key to Economic Growth?" The Quarterly Journal of Economics, 111:269-76

Blonigen, Bruce and Ronald Davies. 2001. "The Effects of Bilateral Tax Treaties on U.S. FDI Activity." University of Oregon Working Paper.

Borner, Silvio, Aymo Brunetti and Beatrice Weder. 1995. "Policy Reform and Institutional Uncertainty: The case of Nicaragua." Kyklos, 48:1:43-64.

Brunetti, Aymo and Beatrice Weder. 1994. "Political Credibility and Economic Growth in Less Developed Countries." Constitutional Political Economy, 5:1:23-43.

Carr, David, James Markusen and Keith Maskus. 2002. Competition for Multinational Investment in Developing Countries: Human Capital, Infrastructure and Market Size. University of Chicago Press, Chicago.

Caves, Richard. 1974. "Multinational Firms, Competition, and Productivity in Host-Country Markets." Economica, 41:176-193.

. 1979. "International Cartels and Monopolies in International Trade", in International Economic Policy: Theory And Evidence, ed. Rudiger Dornbusch and Jacob A. Frankel. Johns Hopkins Press, Baltimore.

University Press, Cambridge.

1996. Multinational Enterprise and Economic Analysis. Cambridge

Chakrabarti, Avik. 2001. "The Determinants of Foreign Direct Investment: Sensitivity Analyses of Cross-Country Regressions." Kyklos, 54:1:89-113.

Coase, Ronald. 1960. “The problem of Social Cost.” Journal of Law and Economics, 3:1-44. 
Comeaux, Paul and Stephen Kinsella. 1994. "Reducing Political Risk in Developing Countries: Bilateral Investment Treaties, Stabalization Clauses, and MIGA \& OPIC Investment Insurance." New York Law School, Journal of International and Comparative Law, 15:1.

Cooper, Richard. 2001. "Growth and Inequality: The Role of Foreign Trade and Investment." Working paper, Harvard University.

Dallago, Bruno. 1996. "Investment, Systemic Efficiency and Distribution.” Kyklos, 49:4:61541.

De Soto, Hernando. 2000. The Mystery Of Capital : Why Capitalism Triumphs In The West And Fails Everywhere Else. Basic Books, New York.

Demsetz, Harold. 1967. "Toward a Theory of Property Rights." American Economic Review, 57:2: 347-359.

Diermeier, Daniel, Joel Ericson, Timothy Frye and Steven Lewis. 1997. "Credible Commitment and Property Rights: The role of strategic interaction between political and economic actors." In Weimer, David. The Political Economy of Property Rights: Institutional change and credibility in the reform of centrally planned economies. Cambridge University Press, New York.

Dobek, Mariusz Mark. 1997. "Property Rights and Institutional Change in the Czech and Slovak Republics." In Weimer, David. The Political Economy of Property Rights: Institutional change and credibility in the reform of centrally planned economies. Cambridge University Press, New York.

Dollar, David. 2001. “Globalization, Inequality, and Poverty since 1980.” World Bank Working Paper. The World Bank, Washington, DC.

Dollar, David and Aart Kraay. 2001. "Trade, Growth, and Poverty.” World Bank Working Paper. The World Bank, Washington, DC.

Dolzer, Rudolf and Margrete Stevens. 1995. Bilateral Investment Treaties, M. Nijhoff Press, The Hague, Boston.

Downs, George David Rocke and Peter Barsoom. 1996. "Is the Good News About Compliance Good News About Cooperation?" International Organization, 50:379-87.

Eggertsson, Thrainn. 1998. "Limits to Institutional Reforms." Scandinavian Journal of Economics, 100:1:335-357.

Fafchamps, Marcel. 1996. "The Enforcement of Commercial Contracts in Ghana." World Development, 24:3:427-448.

Findlay, Ronald. 1978. "Some Aspects of Technology Transfer and Direct Foreign Investment." The American Economic Review, 68:2:275-79. 
Firmin-Sellers, Kathryn. 1995. "The Politics of Property Rights." American Political Science Review, 89:4:867-881.

Gastanaga, Victor, Jeffrey Nugent, and Bistra Pashamova. 1998. "Host Country Reforms and FDI Inflows: How Much Difference Do They Make?” World Development, 26:1299-1313.

Goldsmith, Arthur. 1995. "Democracy, Property Rights and Economic Growth." Journal of Development Studies, 32:2:157-75.

Goldstein, Judith and Lisa Martin. 2000. "Legalization, Trade Liberalization, and Domestic Politics: A Cautionary Note." International Organization, 54:3.

Grabowski, Richard and Michael Shields. 1989. "Lewis and Ricardo: a Reinterpretation." World Development, 17:2:193-98.

Greif, Avner. 2001. "How Do Self-enforcing Institutions Endogenously Change?" Preliminary Chapter, Stanford University.

Guzmán, Andrew. 1997 "Explaining the Popularity of Bilateral Investment Treaties: Why LDCs Sign Treaties that Hurt Them." Harvard Jean Monnet Working Paper 12/97, Harvard Law School, Cambridge MA. 2001. "International Law: A Compliance Based Theory." UC Berkeley School of Law, Public Law and Legal Theory Working Paper No. 47.

Hall, Robert and Charles Jones. 1999. "Why Do Some Countries Produce So Much More Output per Worker than Others?" Quarterly Journal of Economics, 114:1:83-116.

Hanson, Gordon. 2001. “Should Countries Promote Foreign Direct Investment?” G-24 Discussion Paper 9.

Harriss, John, Janet Hunet and Colin Lewis. 1995. The New Institutional Economics and Third World Development. Routledge, London.

Hellman, Joel. 1998. "Winners Take All: The Politics of Partial Reform in Post-communist Transitions," World Politics, 50:2.

Henisz, Witold. 2000. "The Institutional Environment for Economic Growth." Economics and Politics, 12:1:1-31.

Hirschman, Albert. 1970. Exit, Voice, and Loyalty. Harvard University Press, Cambridge, MA. Ho, Daniel. 2002. "Compliance with International Soft Law: Why Do Countries Implement the Basle Accord?” Journal of International Economic Law, 5:3:647-688 
Humphrey, John and Hubert Schmitz. 1998. "Trust And Inter-Firm Relations In Developing And Transition Economies.” Journal of Development Studies, 34:4:32-62.

Irwin, Douglas and Randall Kroszner. 1997. "Interests, Institutions, and Ideology in the Republican Conversion to Trade Liberalization, 1934-1945.” NBER Working Paper No. w6112.

Islam, Roumeen and Claudio Montenegro. 2002. "What Determines the Quality of Institutions?" Background Paper for the World Development Report 2002: Building Institutions for Markets. The World Bank, Washington, DC.

Kahler, Miles. 2000. "Conclusion: The Causes and Consequences of Legalization." International Organization, 54:3:661-683.

Keefer, Philip and Stephen Knack. 1997. "Why Don't Poor Countries Catch Up? A CrossNational Test of an Institutional Explanation." Economic Inquiry, 35:590-602.

Kishoiyian, Bernard. 1994. "The Utility of Bilateral Investment Treaties in the Formulation of Customary International Law." Journal of International Law \& Business, 14:327.

Klein, Michael, Carl Aaron and Bita Hadjmichael. 2001. "Foreign Direct Investment and Poverty Reduction." New Horizons and Policy Challenges for Foreign Direct Investment in the $21^{\text {st }}$ Century. Mexico City. World Bank Working Paper. The World Bank, Washington, DC.

Knack, Stephen and Philip Keefer. 1995. "Institutions and Economic Performance: CrossCountry Tests Using Alternative Institutional Measures.” Economics and Politics, 7:3:207-227.

Kofele-Kale, Ndiva. 1992. "The Political Economy Of Foreign Direct Investment: A Framework For Analyzing Investment Laws And Regulations In Developing Countries." Law and Policy in International Business, 23:619-71.

Koizumi, Tetsunori and Kenneth Kopecky. 1980. "Foreign Direct Investment, Technology Transfer and Domestic Employment Effects". Journal of International Economics, 10:1-20.

La Porta, Rafael, Florencio Lopez-de-Silanes, Andrei Shleifer, and Robert Vishny. 2000. "Investor Protection and Corporate Governance." Journal of Financial Economics, 58: 3-27.

Lall, Sanjaya and Paul Streeten. 1977. Foreign Investment, Transnationals and Developing Countries. Westview Press, Colorado.

Landes, David. 1998. The Wealth and Poverty of Nations, Why Some Are So Rich And Some So Poor. WW Norton, New York.

Lankes, Hans-Peter and Toney Venables. 1996. "Foreign Direct Investment in economic transition: the changing pattern of investment." Economics of Transition, 4:2:331-348. 
LCHR: Lawyers Committee for Human Rights. 2000. "Building On Quicksand: The Collapse Of The World Bank's Judicial Reform Project In Peru.” LCHR Working Paper.

Leblang, David. 1996. "Property Rights, Democracy And Economic Growth.” Political Research Quarterly, 49:1:5-27

Libecap, Gary. 1989. Contracting For Property Rights. Cambridge University Press, New York.

Lipsey, Robert. 2001. "Foreign Direct Investment And The Operations Of Multinational Firms: Concepts, History, And Data.” NBER Working Paper Series: Working Paper 8665

Lorenz, Edward. 1999. "Trust, Contract and Economic Cooperation." Cambridge Journal of Economics, 23:301-315.

Mansfield, Edwin and Anthony Romeo. 1980. "Technology Transfer to Overseas Subsidiaries by US Based Firms.” Quarterly Journal of Economics, 95:4:737-50.

Markusen, James. 1990. "First Mover Advantage, Blockaded Entry, and the Economics of Uneven Development.” NBER Working Paper Series: Working Paper No. 3284.

Martin, Lisa and Beth Simmons. 1998. "Theories and Empirical Studies of International Institutions." International Organization, 52:4:729-757.

. 2002. "International Organisations and Institutions." Chapter

9, Handbook of International Relations. Sage Publications.

Mataloni, Raymond. 1995. Guide to BEA Statistics on U.S. Multinational Companies. Survey of Current Business, March. Washington: U.S. Department of Commerce, Bureau of Economic Analysis.

Mckinstry Robin, Patricia. 1984. "The BIT Won't Bite: The American Bilateral Investment Treaty Program.” American University Law Review, 33:931.

Nash, Marian. 1993. "U.S. Practice: Bilateral Investment Treaties." The American Journal International Law, 87:433

Ndikumana, Leonce. 2001. "Financial Determinants of Domestic Investment in Sub-Saharan Africa: Evidence from Panel Data." World Development, 28:2:381-400.

North, Douglass. 1981. Structure and Change in Economic History. W.W. Norton, New York.

World Development, 17:9. 
University Press, Cambridge.

1990. Institutions, Institutional Change and Economic Growth. Cambridge

North, Douglass and Barry Weingast. 1989. "Constitutions and Commitment: The Evolution of Institutional Governing Public Choice in Seventeenth-Century England." The Journal of Economic History, 49:4:803-832.

Olson, Mancur. 1965. The Logic of Collective Action. Harvard University Press, Cambridge, MA.

. 1993. "Dictatorship, Democracy, and Development." American Political Science Review, 87: 567-76.

Ozler, Sule, and Dani Rodrik. 1992. "External Shocks, Politics and Private Investment: Some Theory and Empirical Evidence," NBER Working Paper No. 3960.

Pistoresi, Barbara. 2000. "Investimenti diretti esteri e fattori di localizzazione: L'America Latina e il Sud Est asiatico" ("Foreign Direct Investment and Factor Localization: Latin America and South East Asia"), Rivista di Politica Economica, 90:27-44.

Quijano, Alicia. 1990. "A Guide to BEA Statistics on Foreign Direct Investment in the United States." Survey of Current Business, 70:2:29-37.

Rapaczynski, Andrzej. 1996. "The Roles of the State and the Market in Establishing Property Rights." The Journal of Economic Perspectives, 10:2:87-103.

Reading, Michael. 1992. "Note: The Bilateral Investment Treaty In Asean: A Comparative Analysis." Duke Law Journal. 42:679.

Riker, William and Itai Sened. 1991. "A Political Theory of the Origins of Property Rights: Airport Slots." American Journal of Political Science, 35:4: 951-969.

Ritzen, Jo, William Easterly, and Michael Woolcock. 2000. "On 'Good' Politicians and "Bad" Policies: Social Cohesion, Institutions, and Growth.” World Bank Working Paper. World Bank, Washington DC.

Rodden, Jonathan, and Susan Rose-Ackerman. 1997. "Does Federalism Preserve Markets?" University of Virgina Law Review, 83:1521-1572.

Root, Franklin and Ahmed Ahmed. 1979. "Empirical Determinants of Manufacturing Direct Foreign Investment in Developing Countries", Economic Development and Cultural Change, 27:751-767.

Rose-Ackerman, Susan. 1985. "Inalienability and The Theory of Property Rights," Columbia Law Review 85:931-969. 
1999. Corruption and Government: Causes, Consequences, and Reform. Cambridge University Press, Cambridge UK.

2001a. "Trust, Honesty, and Corruption: Reflections on the State-Building Process," Archives of European Sociology, 42: 526-570. . 2001b. "Trust and Honesty in Post-Socialist Societies," Kyklos, 54: 415-

444.

2002 "Corruption and the Global Corporation: Ethical Obligations and Workable Strategies," in Michael Likosky, ed. Transnational Legal Processes. Butterworths, London.

Rose-Ackerman, Susan, and Jim Rossi. 2000. "Disentangling Deregulatory Takings," Virginia Law Review 86: 1435-1495.

Rose-Ackerman, Susan, and Jennifer Tobin. 2002. "Foreign Direct Investment in Developing Countries: Does It Matter and How Would We Know?” Draft, Yale University, New Haven CT.

Rosendorff, Peter and Helen Milner. 2001. "The Optimal Design of International Trade Institutions: Uncertainty and Escape. International Organization, 13:1:1-29.

Sader, Frank. 1993. "Privatization and Foreign Investment in the Developing World," World Bank Working Paper No. 1202.

Schmidt-Hebbel, Klaus, Luis Serven, and Andres Solimano. 1996. "Saving and Investment: Paradigms, Puzzles, Policies," World Bank Research Observer, 11:1:87-117.

Schneider, Friedrich and Bruno Frey. 1985. "Economic And Political Determinants Of Foreign Direct Investment.” World Development, 13:161-75.

Schwarzenberger, George. 1969. Foreign Investment and International Law. Stevens and Son Press, London.

Shenkin, Todd. 1994. "Trade-Related Investment Measures In Bilateral Investment Treaties And The Gatt: Moving Toward A Multilateral Investment Treaty." University of Pittsburgh Law Review, 541.

Simmons, Beth. 2000. "International Law and State Behavior: Commitment and Compliance in International Monetary Affairs." American Political Science Review, 94:4:819.

Slaughter, Anne-Marie. 1995. "International Law in a World of Liberal States.” European Journal of International Law, 6:503.

Soskice, David, Robert Bates and David Epstein. 1992. "Ambition and Constraint: The Stabilizing Role of Institutions." Journal of Law, Economics, and Organization, 8:3. 
Torstensson, Johan. 1994. "Property rights and economic growth: an empirical study," Kyklos. 47:2:231-48

Toye, John. 1995. "The New Institutioanl Economics and its Implications for Development Theory." In Harriss, John, Janet Hunet and Colin Lewis, eds.. The New Institutional Economics and Third World Development. Routledge, London.

UNCTAD. 2001. Bilateral Investment Treaties 1959-1999. United Nations, New York and Geneva.

New York and Geneva.

1998. Bilateral Investment Treaties in the Mid-1990s. United Nations, 1996. Division on Transnational Corporations and Investment, "Incentives and Foreign Direct Investment." Current Studes series A, No. 30. New York and Geneva.

Waelde, Thomas. 1999. "International Treaties and Regulatory Risk." World Bank Working Paper. World Bank, Washington, DC.

Wai, U Tun and Chorng-Huey Wong. 1982. "Determinants of Private Investment in Developing Countries.” Journal of Development Studies, 19:1:19-36.

Walker, Herman. 1956. "Treaties for the Encouragement and Protection of Foreign Investment. Present United States Practice,” American Journal of Competition Law, 229.

Weimer, David. 1997. The Political Economy of Property Rights: Institutional change and credibility in the reform of centrally planned economies. Cambridge University Press, New York.

Weingast, Barry. 1997. "The Political Commitment to Markets and Marketization." In David Weimer, 1997. The Political Economy of Property Rights: Institutional change and credibility in the reform of centrally planned economies. Cambridge University Press, New York.

Wheeler, David and Ashoka Mody. 1992. "International Investment Location Decisions: The Case of US Firms," Journal of International Economics, 33:57-76. 


\section{WILLIAM DAVIDSON INSTITUTE WORKING PAPER SERIES}

The Working Paper Series may be downloaded free of charge at: www.wdi.bus.umich.edu

CURRENT AS OF 6/30/03

\begin{tabular}{|c|c|c|}
\hline Publication & Authors & Date \\
\hline $\begin{array}{l}\text { No. 587: Foreign Direct Investment and the Business Environment in } \\
\text { Developing Countries: the Impact of Bilateral Investment Treaties }\end{array}$ & $\begin{array}{l}\text { Jennifer Tobin and Susan Rose- } \\
\text { Ackerman }\end{array}$ & June 2003 \\
\hline No. 586: Trust in China: A Cross-Regional Analysis & Rongzhu Ke and Weiying Zhang & June 2003 \\
\hline No. 585: Family Control and the Rent-Seeking Society & $\begin{array}{l}\text { Randall Morck and Bernard } \\
\text { Yeung }\end{array}$ & June 2003 \\
\hline $\begin{array}{l}\text { No. 584: Wage Determination: Privatised, New Private and State } \\
\text { Owned Companies, Empirical Evidence from Panel Data }\end{array}$ & $\begin{array}{l}\text { Tomasz Mickiewicz and Kate } \\
\text { Bishop }\end{array}$ & June 2003 \\
\hline No. 583: An Investigation of Firm-Level R\&D Capabilities in East Asia & $\begin{array}{l}\text { Gary H. Jefferson and Zhong } \\
\text { Kaifeng }\end{array}$ & June 2003 \\
\hline $\begin{array}{l}\text { No. 582: R\&D and Technology Transfer: Firm Level Evidence From } \\
\text { Chinese Industry }\end{array}$ & $\begin{array}{l}\text { Albert G.Z. Hu, Gary H. } \\
\text { Jefferson, Guan Xiaojing and } \\
\text { Qian Jinchang }\end{array}$ & June 2003 \\
\hline $\begin{array}{l}\text { No. 581: Credit Market Disequilibrium in Poland: Can We Find } \\
\text { What We Expect? Non-Stationarity and the "Min" } \\
\text { Condition }\end{array}$ & $\begin{array}{l}\text { Christophe Hurlin†and Rafal } \\
\text { Kierzenkowski }\end{array}$ & June 2003 \\
\hline $\begin{array}{l}\text { No. 580: Does it Take a Lula to go to Davos? } \\
\text { A Brief Overview of Brazilian Reforms, 1980-2000 }\end{array}$ & $\begin{array}{l}\text { Nauro F. Campos, Armando } \\
\text { Castellar Pinheiro, Fabio } \\
\text { Giambiagi and Maurício M. } \\
\text { Moreira }\end{array}$ & June 2003 \\
\hline $\begin{array}{l}\text { No. 579: Ceaseless Toil? Health and Labor Supply of the Elderly in } \\
\text { Rural China }\end{array}$ & $\begin{array}{l}\text { Dwayne Benjamin, Loren Brandt } \\
\text { and Jia-Zhueng Fan }\end{array}$ & June 2003 \\
\hline $\begin{array}{l}\text { No. 578: Shadow Economy, Rent-Seeking Activities and the Perils of } \\
\text { Reinforcement of the Rule of Law }\end{array}$ & Ekaterina Vostroknutova & June 2003 \\
\hline $\begin{array}{l}\text { No. 577: No Pain, No Gain: Market Reform, Unemployment, and } \\
\text { Politics in Bulgaria }\end{array}$ & Neven Valev & June 2003 \\
\hline $\begin{array}{l}\text { No. 576: Power Analysis of the Nice Treaty On the Future of European } \\
\text { Integration }\end{array}$ & Yener Kandogan & June 2003 \\
\hline $\begin{array}{l}\text { No. 575: Democracy’s Spread: Elections and Sovereign Debt in } \\
\text { Developing Countries }\end{array}$ & $\begin{array}{l}\text { Steven A. Block, Burkhard N. } \\
\text { Schrage, and Paul M. Vaaler }\end{array}$ & June 2003 \\
\hline $\begin{array}{l}\text { No. 574: Reintroducing Intergenerational Equilibrium: Key Concepts } \\
\text { Behind the New Polish Pension System }\end{array}$ & Marek Góra & June 2003 \\
\hline $\begin{array}{l}\text { No. 573: Why Does FDI Go Where It Goes? New Evidence From the } \\
\text { Transition Economies }\end{array}$ & $\begin{array}{l}\text { Yuko Kinoshita and Nauro F. } \\
\text { Campos }\end{array}$ & June 2003 \\
\hline $\begin{array}{l}\text { No. 572: Private Savings in Transition Economies: Are There Terms of } \\
\text { Trade Shocks? }\end{array}$ & Abdur R. Chowdhury & May 2003 \\
\hline $\begin{array}{l}\text { No. 571: On the long-run determinants of real exchange rates for } \\
\text { developing countries: Evidence from Africa, Latin America and Asia }\end{array}$ & Imed Drine and Christophe Rault & May 2003 \\
\hline $\begin{array}{l}\text { No. 570: A re-examination of the Purchasing Power Parity using non- } \\
\text { stationary dynamic panel methods: a comparative approach for } \\
\text { developing and developed countries }\end{array}$ & Imed Drine and Christophe Rault & May 2003 \\
\hline $\begin{array}{l}\text { No. 569: How Important is Ownership in a Market with Level Playing } \\
\text { Field? The Indian Banking Sector Revisited }\end{array}$ & $\begin{array}{l}\text { Sumon Kumar Bhaumik and } \\
\text { Ralitza Dimova }\end{array}$ & May 2003 \\
\hline $\begin{array}{l}\text { No. 568: On Types of Trade, Adjustment of Labor and Welfare Gains } \\
\text { During Asymmetric Liberalizations }\end{array}$ & Yener Kandogan & May 2003 \\
\hline $\begin{array}{l}\text { No. 567: Technological Progress Through Trade Liberalization in } \\
\text { Transition Countries }\end{array}$ & Yener Kandogan & May 2003 \\
\hline $\begin{array}{l}\text { No. 566: Intra-industry Trade of Transition Countries: Trends and } \\
\text { Determinants }\end{array}$ & Yener Kandogan & May 2003 \\
\hline $\begin{array}{l}\text { No. 565: Local Protectionism and Regional Specialization: Evidence } \\
\text { from China's Industries }\end{array}$ & $\begin{array}{l}\text { Chong-En Bai, Yingjuan Du, } \\
\text { Zhigang Tao, and Sarah Y. Tong }\end{array}$ & May 2003 \\
\hline
\end{tabular}

